\title{
RECEIVED
}

JAN 261996

OS.TI

\section{Contamination Source Review for Building E3180, Edgewood Area, Aberdeen Proving Ground, Maryland}

Energy Systems Division

Argonne National Laboratory

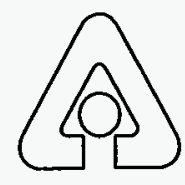

Operated by The University of Chicago, under Contract W-31-109-Eng-38, for the

United States Department of Energy 


\section{Argonne National Laboratory}

Argonne National Laboratory, with facilities in the states of Illinois and Idaho, is owned by the United States Government, and operated by the University of Chicago under the provisions of a contract with the Department of Energy.

This technical memo is a product of Argonne's Energy Systems (ES) Division. For information on the division's scientific and engineering activities, contact:

Director, Energy Systems Division

Argonne National Laboratory

Argonne, Illinois 60439-4815

Telephone (708) 252-3724

Presented in this technical memo are preliminary results of ongoing work or work that is more limited in scope and depth than that described in formal reports issued by the ES Division.

Publishing support services were provided by Argonne's Information and Publishing Division (for more information, see IPD's home page: http://uww.ipd.anl.gov).

\section{Disclaimer}

This report was prepared as an account of work sponsored by an agency of the United States Government. Neither the United States Government nor any agency thereof, nor any of their employees, makes any warranty, express or implied, or assumes any legal liability or responsibility for the accuracy, completeness, or usefulness of any information, apparatus, product, or process disclosed, or represents that its use would not infringe privately owned rights. Reference herein to any specific commercial product, process, or service by trade name, trademark, manufacturer, or otherwise, does not necessarily constitute or imply its endorsement, recommendation, or favoring by the United States Government or any agency thereof. The views and opinions of authors expressed herein do not necessarily state or reflect those of the United States Government or any agency thereof. 


\section{Contamination Source Review for Building E3180, Edgewood Area, Aberdeen Proving Ground, Maryland}

S.D. Zellmer, M.P. Smits, J. Rueda, and R.E. Zimmerman

Center for Environmental Restoration Systems, Energy Systems Division,

Argonne National Laboratory, 9700 South Cass Avenue, Argonne, Illinois 60439

Published as
Contamination Source Review
Edgewood Area, Aberdeen Proving
Ground, Maryland-
Building E3180

September 1995

Work sponsored by United States Department of Defense, United States Army, Aberdeen Proving Ground, Maryland 
This report is printed on recycled paper. 


\section{Contents}

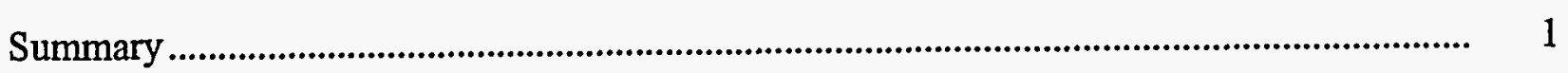

1 Introduction.............................................................................................................. 3

2 Methodology .............................................................................................................. 5

3 Historical Record Search ............................................................................................. 6

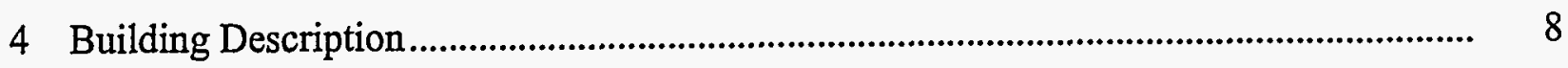

4.1 Site Description................................................................................................... 8

4.1.1 Location .............................................................................................. 8

4.1.2 Proximity to Other Buildings...................................................................... 8

4.1.3 Building Structure............................................................................................. 8

4.1.4 Exterior Dimensions ................................................................................ 11

4.1.5 Topography .............................................................................................. 11

4.1.6 Vegetation in the Immediate Vicinity ........................................................... 11

4.1.7 External Aboveground Structures or Equipment........................................... 11

4.1.8 Connections with Adjacent Buildings........................................................... 11

4.1.9 Underground Structures ............................................................................... 11

4.1.10 Surface Drainage System........................................................................ 12

4.1.11 Utility Access Points................................................................................... 12

4.1.12 Exterior Piping .................................................................................... 12

4.1.13 Nearby Roads and Sidewalks.................................................................... 12

4.2 North Exterior Elevation....................................................................................... 12

4.2.1 Dimensions........................................................................................ 12

4.2.2 Construction Materials............................................................................... 12

4.2.3 Doors and Windows.............................................................................. 12

4.2.4 Piping ................................................................................................. 13

4.2.5 Utility Connections ...................................................................................

4.2.6 External Equipment or Structures ................................................................ 13

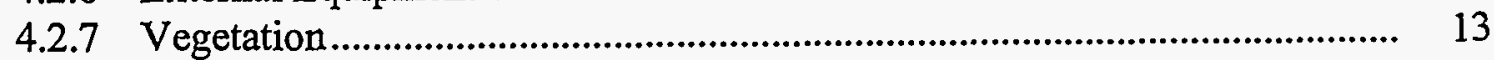

4.2.8 Overall Condition..................................................................................... 13

4.3 East Exterior Elevation ........................................................................................... 13

4.3.1 Dimensions.............................................................................................. 13

4.3.2 Construction Materials.................................................................................... 14

4.3.3 Doors and Windows................................................................................. 14

4.3.4 Piping ................................................................................................... 14

4.3.5 Utility Connections ....................................................................................... 14

4.3.6 External Equipment or Structures ............................................................... 14

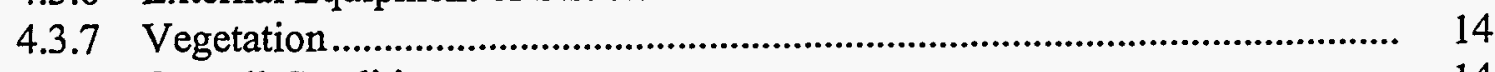

4.3.8 Overall Condition........................................................................................... 14 


\section{Contents (Cont.)}

4.4 South Exterior Elevation....................................................................................

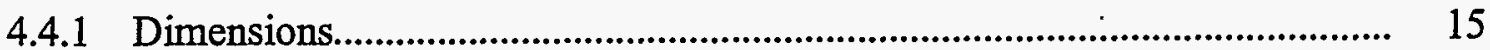

4.4.2 Construction Materials.......................................................................... 15

4.4.3 Doors and Windows................................................................................ 15

4.4.4 Piping ....................................................................................... 15

4.4.5 Utility Connections ..................................................................................... 15

4.4.6 External Equipment or Structures.................................................................. 15

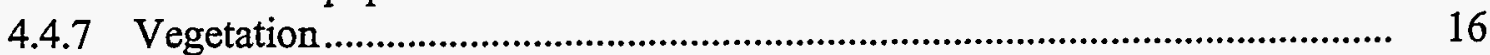

4.4.8 Overall Condition....................................................................................... 16

4.5 West Exterior Elevation ............................................................................... 16

4.5.1 Dimensions.......................................................................................... 16

4.5.2 Construction Materials.......................................................................... 16

4.5.3 Doors and Windows................................................................................ 16

4.5.4 Piping .......................................................................................... 16

4.5.5 Utility Connections ..................................................................................... 17

4.5.6 External Equipment or Structures .................................................................. 17

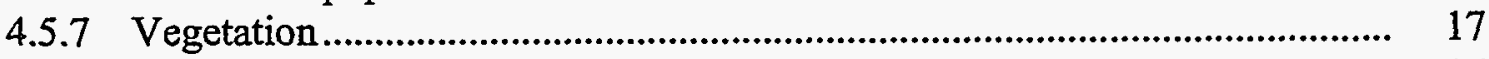

4.5.8 Overall Condition............................................................................... 17

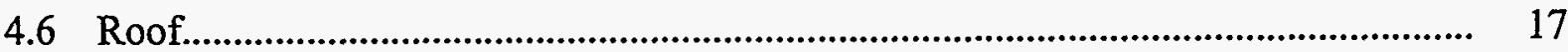

4.6.1 Type and Dimensions............................................................................. 17

4.6.2 Height.......................................................................................... 17

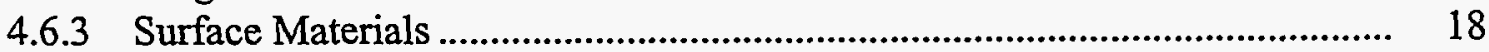

4.6.4 Support System ................................................................................. 18

4.6.5 Condition........................................................................................... 18

4.6.6 Equipment Located on Roof...................................................................... 18

4.6.7 Chimneys, Roof Vents, or Vent Stacks......................................................... 18

4.6.8 Piping ...................................................................................................... 18

4.7 Interior Floor Plan............................................................................................ 19

4.7.1 Room Numbers and Dimensions ................................................................ 19

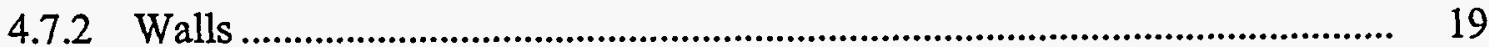

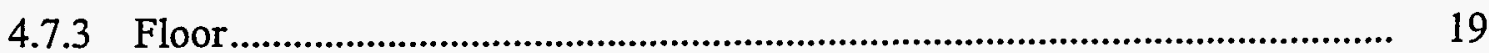

4.7.4 Floor Penetrations ................................................................................. 20

4.7.5 Interior Partitions ...................................................................................... 20

4.7.6 Equipment or Supplies ............................................................................ 20

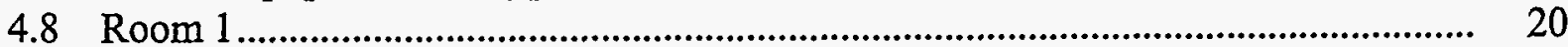

4.8.1 Walls ....................................................................................................... 20

4.8.2 Finish Materials................................................................................. 20

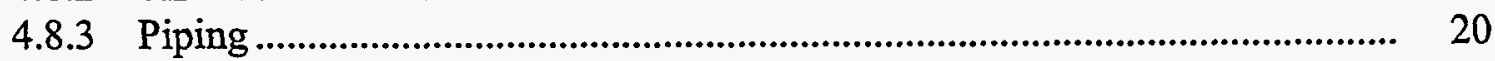

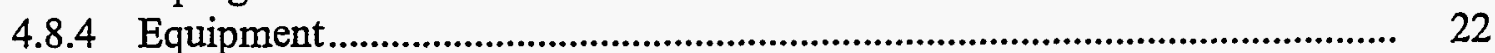

4.8.5 Doors and Windows......................................................................... 22

4.8.6 Ceiling...................................................................................... 22

4.8 .7 Floor ..................................................................................................... 22 


\section{Contents (Cont.)}

4.9 Room 2

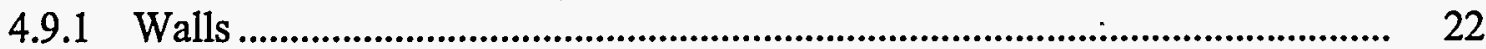

4.9.2 Finish Materials.................................................................................... 22

4.9.3 Piping ........................................................................................................ 25

4.9.4 Equipment ............................................................................................... 25

4.9.5 Doors and Windows............................................................................ 25

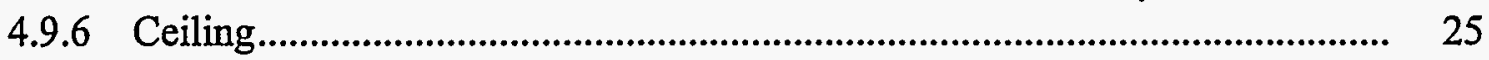

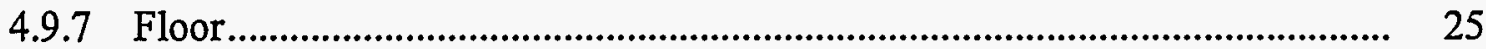

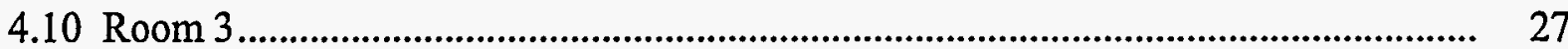

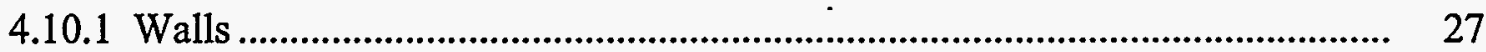

4.10.2 Finish Materials..................................................................................... 27

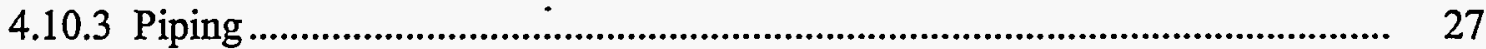

4.10.4 Equipment .................................................................................................... 27

4.10.5 Doors and Windows............................................................................ 27

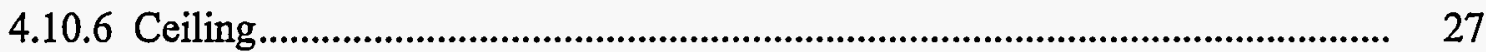

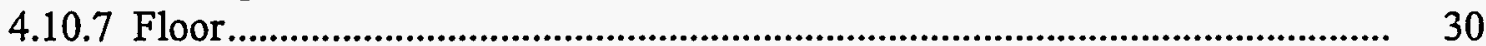

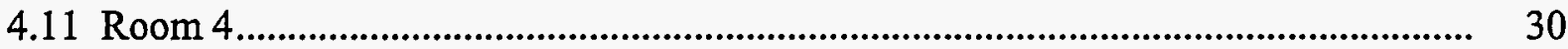

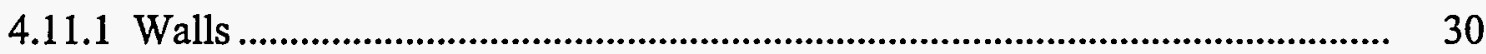

4.11.2 Finish Materials...................................................................................... $\quad 30$

4.11.3 Piping ............................................................................................... 30

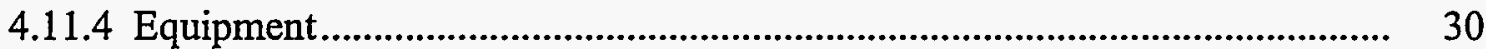

4.11.5 Doors and Windows............................................................................ 30

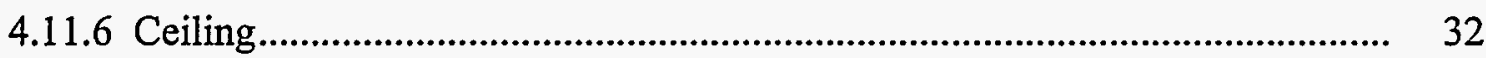

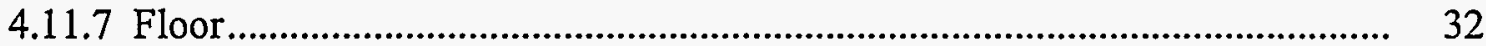

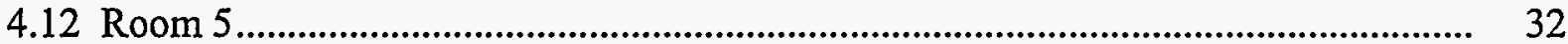

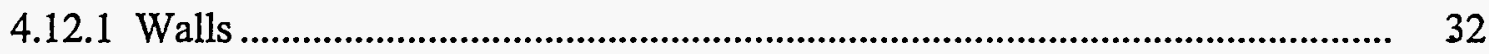

4.12.2 Finish Materials...................................................................................... 32

4.12.3 Piping .............................................................................................. 32

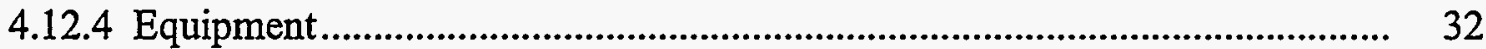

4.12.5 Doors and Windows......................................................................... 34

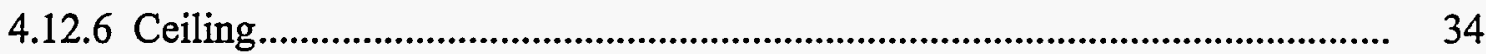

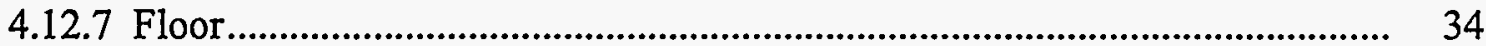

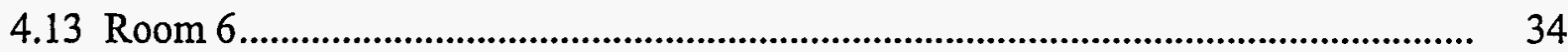

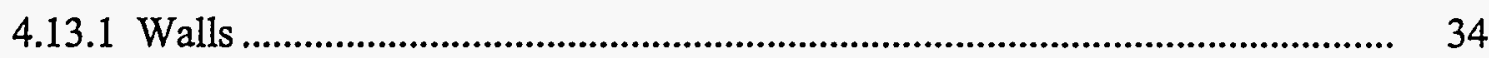

4.13.2 Finish Materials.................................................................................. 34

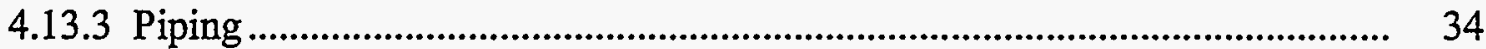

4.13.4 Equipment........................................................................................... 35

4.13.5 Doors and Windows............................................................................ 35

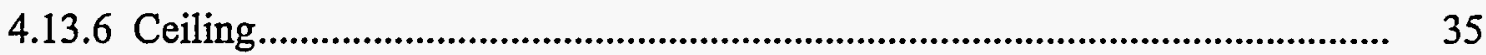

4.13.7 Floor ................................................................................................ 35

5 Geophysical Investigation............................................................................................... 36 


\section{Contents (Cont.)}

$6 \quad$ Air Quality Investigation ........................................................................................... 37

$7 \quad$ Underground Storage Tanks ........................................................................................ 38

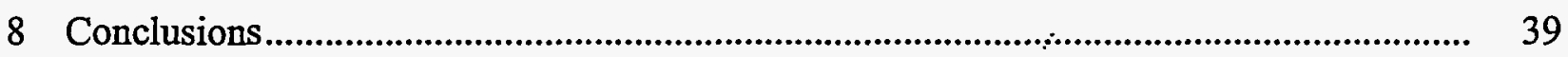

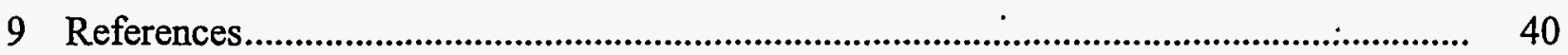

Appendix A: Interim Progress Report - Environmental Geophysics:

Building E3180 Decommissioning, Aberdeen Proving Ground.......................... 41

Appendix B: Air Quality Monitoring Report.......................................................................... 79

Figures

1 Map of Aberdeen Proving Ground Location ......................................................................... 4

2 Map of Building E3180 Location ...................................................................................... 7

3 Building E3180 Floor Plan .....................................................................................

4 Photographs of Building E3180 Exterior........................................................................... 10

5 Photographs of Room 1 - Walls ................................................................................... 21

6 Photographs of Room 1 - Ceiling and Floor ............................................................... 23

7 Photographs of Room 2 - Walls .................................................................................. 24

8 Photographs of Room 2 - Ceiling and Floor ............................................................... 26

9 Photographs of Room 3 - Walls .................................................................................. 28

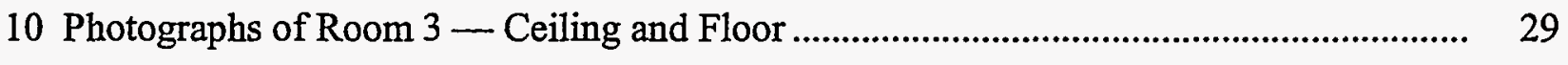

11 Photographs of Room 4 - Walls ....................................................................................... 31

12 Photographs of Room 4 - Ceiling and Floor ................................................................... 33 


\title{
Contamination Source Review for Building E3180, Edgewood Area, Aberdeen Proving Ground, Maryland
}

\author{
by \\ S. D. Zellmer, M.P. Smits, J. Rueda, \\ and R.E. Zimmerman
}

\section{Summary}

This report was prepared by Argonne National Laboratory (ANL) to document the results of a contamination source review of Building E3180 at the Aberdeen Proving Ground (APG) in Maryland. The report may be used to assist the U.S. Army in planning for the future use or disposition of this building. The review included a historical records search, physical inspection, photographic documentation, geophysical investigation, collection of air samples, and review of available records regarding underground storage tanks associated with Building E3180. The field investigations were performed by ANL during 1994.

Building E3180 (current APG designation) is located near the eastern end of Kings Creek Road, north of Kings Creek, and about 0.5 miles east of the airstrip within APG's Edgewood Area. The building was constructed in 1944 as a facsimile of a Japanese pillbox and used for the development of flame weapons systems until 1957 (EAI Corporation 1989). The building was not used from 1957 until 1965, when it was converted and used as a flame and incendiary laboratory. During the 1970s, the building was converted to a machine (metal) shop and used for that purpose until 1988.

The physical inspection and photographic documentation of Building E3180 were completed in November 1994. The building is a single-story structure that contains six rooms. The main portion of the building measures $32 \mathrm{ft}$ long, $14 \mathrm{ft}$ wide, and $7 \mathrm{ft} \mathrm{high}$; contains five rooms; and is constructed of 8-in.-thick cinder block exterior walls. This part of the building has a concrete floor and a flat, built-up asphalt roof over concrete panels. There are two cinder block extensions on the building: one pillbox extension on the east wall and a second extension on the north wall that houses an open (squirrel cage) ventilation system with a sheet-metal stack. Interior walls in this portion of the building are constructed of cinder block coated with white paint. A porch measuring $17 \mathrm{ft}$ long, $6 \mathrm{ft}$ wide, and $7 \mathrm{ft}$ high extends from the west side of the main portion of the building. This porch has fine mesh wire screen walls supported by wood framing, a wood floor, a wood ceiling, and an asphalt roof.

At the time of the ANL inspection, one room of the building (room 5) was sealed, preventing inspection. Some of the other rooms contained electric heaters, lighting fixtures, electrical outlets, and electrical conduits attached to the walls and ceilings. 
During June and July 1994, ANL staff conducted geophysical surveys in the immediate vicinity of Building E3180 by using several nonintrusive methods. Survey results suggest the presence of some underground objects near Building E3180, but they do not provide conclusive evidence of the source of the geophysical anomalies observed during the surveys.

Air quality samples were collected upwind, downwind, and inside Building E3180 in November 1994. Analytical results showed no distinguishable difference in the hydrocarbon and chlorinated solvent levels between the two background samples and the sample collected inside Building E3180. These results indicate that Building E3180 is not a source of volatile organic compound contamination.

No information regarding underground storage tanks associated with Building E3180 was available.

On the basis of information collected and reviewed by ANL for Building E3180, it is the authors' judgment that potential undetermined contamination could be present in room 5 of the building. No significant air contamination is associated with the other rooms in the building. Results of the geophysical surveys indicate some anomalies near Building E3180 that warrant further investigation and evaluation. An inspection and monitoring of room 5 is also recommended. 


\section{Introduction}

The U.S. Army Aberdeen Proving Ground (APG) commissioned Argonne National Laboratory (ANL) to conduct a contamination source review to identify and define areas of toxic or hazardous contaminants and to assess the physical condition and accessibility of APG buildings. The information obtained from this review may be used to assist the U.S. Army in planning for the future use or disposition of the buildings. The contamination source review consisted of the following tasks: historical records search, physical inspection, photographic documentation, geophysical investigation, and collection of air quality samples. This report provides the results of the contamination source review for Building E3180.

Located on Chesapeake Bay in Harford and Baltimore counties, Maryland, APG occupies approximately 30,000 acres. The facility is divided into the Aberdeen and Edgewood Areas (Figure 1). The primary mission at APG has been the testing and evaluation of U.S. Army warfare materials. Since its beginning in 1917, the Edgewood Area of APG has been the principal location for chemical warfare agent research, development, and testing in the United States. APG was also used for producing chemical warfare agents during both world wars and has been a center for the storage of chemical warfare material (Nemeth 1989).

Many of the APG facilities constructed between 1917 and the 1960s are no longer used because of obsolescence and their poor state of repair. Because many of these buildings were used for research, development, testing, and/or pilot-scale production of chemical warfare agents and other military substances (such as incendiary materials or munitions containing these materials), the potential exists for portions of these buildings to be contaminated with these substances, their degradation products, and other laboratory or industrial chemicals. These buildings and associated structures or appurtenances (e.g., underground or aboveground storage tanks, pipes, sumps) may contribute to environmental concerns at APG. 


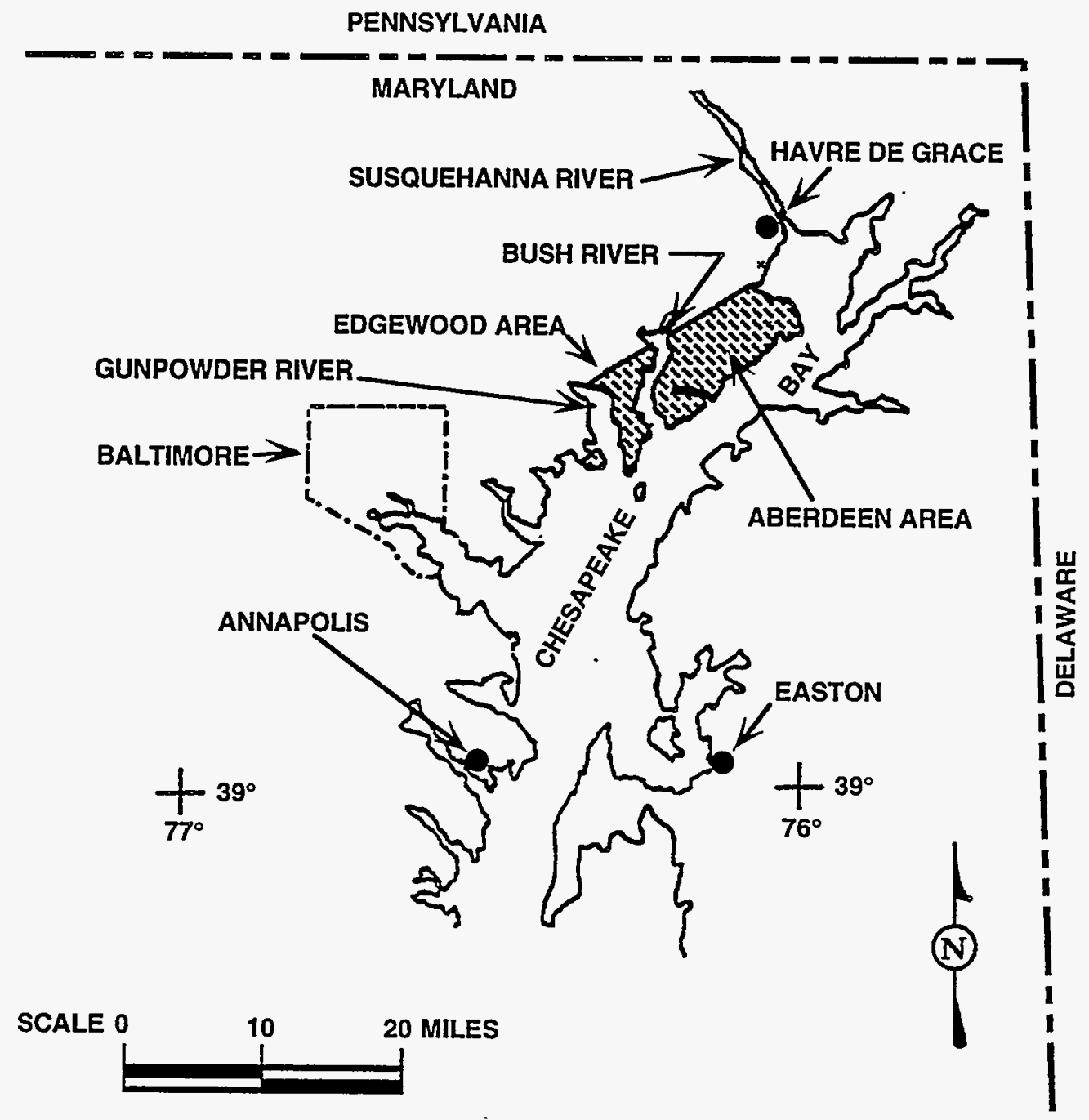

TIS SHADED AREA INDICATES

ABERDEEN PROVING GROUND

FIGURE 1 Map of Aberdeen Proving Ground Location 


\section{Methodology}

Before the detailed building inspection, ANL personnel made a preliminary site visit to locate the building and obtain building records from APG, identify potential issues to be addressed in the health and safety plan, resolve any access restriction issues, and identify required support services.

Photographs were taken of the building's exterior and interior surfaces during the building inspection in November 1994. The photographs followed a set sequence whenever possible. The exterior was photographed starting on the north side and continuing clockwise around the building; walls were photographed starting in the north or northwest corner of each room and continuing clockwise until reaching the starting point. The ceiling and floor of each room were also photographed. No interior inspection or photographs were made in room 5 because the room was sealed.

The area around Building E3180 was examined during the summer of 1994 using several nonintrusive geophysical survey methods, including magnetic gradiometer, total-field magnetics, electrical conductivity (EM-31), induced electromagnetic field (EM-61), and ground-penetrating radar (GPR) techniques.

ANL staff collected air quality samples outside and inside of Building E3180 during November 1994. Organic compounds from 24-L samples trapped in a sorbent polymer cartridge were thermally desorbed and analyzed by using a gas chromatograph equipped with a mass spectrometer. Compounds were identified on the basis of mass spectral interpretation and a computer search of the 140,000 compounds in the Wiley spectral library.

Detailed descriptions of the methodologies used for the geophysical investigation and air quality monitoring are provided in the appendices to this report. 


\section{Historical Record Search}

Building E3180 (current APG designation) is located near the eastern end of Kings Creek Road, north of Kings Creek, and about 0.5 miles east of the airstrip within APG's Edgewood Area (Figure 2). Building E3180 was constructed in 1944 as a facsimile of a Japanese pillbox (EAI Corporation 1989). The building was used by the research and development community in the development of flame weapons systems. The materials used in this effort and unknown. EAI Corporation also reports that the building was not used from 1957 until 1965.

The building was converted to a flame and incendiary laboratory in 1965 and employed for this purpose until the 1970s. Materials uses during experiments were plasticized white phosphorous (PWP), white phosphorous (WP), eutectic white phosphorous (EWP), triethyl aluminum (TEA), napalm non-agent (unknown) thickener, red phosphorous, thermite, and magnesium. Only laboratory-scale amounts of incendiaries were used for the experiments, and all were consumed during testing (EAI Corporation 1989). Building E3180 was designed as a laboratory and listed as Building 379D in the 1966 and 1976 Facility Listings for APG (Nemeth 1989).

Building E3180 was converted to a machine (metal) shop in the 1970s and was employed for this purpose until 1988. Potential contaminants used during this period include petroleum, oil and lubricants (POL), and other (unknown) solvents. There is no record indicating that chemical agents were used in the building (EAI Corporation 1989). 


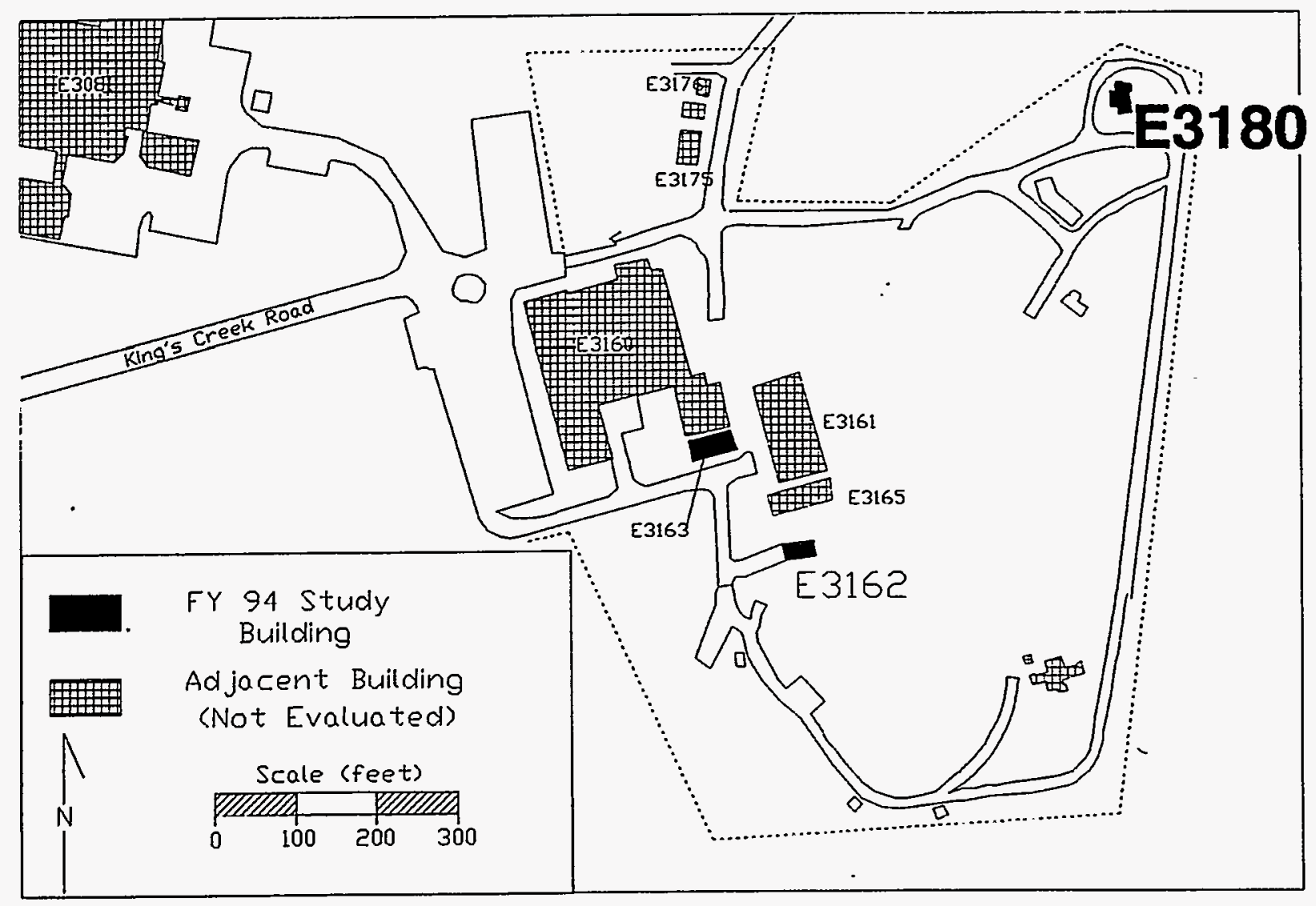

FIGURE 2 Map of Building E3180 Location 


\section{Building Description}

This section provides a detailed physical description of Building E3180 and the surrounding site as they appeared during the ANL inspection in November 1994. This physical description includes an account of the condition of the exterior walls, roof, interior walls, ceiling, and floor of the building. At the time of the ANL inspection, one room of the building (room 5) was sealed, preventing inspection. Some of the rooms had electric heaters, lighting fixtures, electrical outlets, and electrical conduits attached to the walls and ceilings. An open (squirrel cage) ventilation system with a sheet-metal stack was attached to the north exterior of the building.

\subsection{Site Description}

\subsubsection{Location}

Building E3180 is located near the eastern end of Kings Creek Road, north of Kings Creek, and about 0.5 miles east of the airstrip within APG's Edgewood Area (Figure 2).

\subsubsection{Proximity to Other Buildings}

Building E3180 is located approximately $475 \mathrm{ft}$ northeast of Building E3163 (Figure 2).

\subsubsection{Building Structure}

Building E3180 is a single-story structure that contains six rooms. The rectangular main portion contains five rooms, and is constructed of 8-in.-thick cinder block exterior walls with a concrete floor and a flat built-up asphalt roof over concrete panels. There are two cinder block extensions on the building: one pillbox extension near the northeast corner of the east wall and a second near the northwest corner of the north wall that houses an open (squirrel cage) ventilation system with a sheet-metal stack. A porch (room 6) with fine mesh wire screen walls supported by wood framing, a wood floor, a wood ceiling, and an asphalt roof extends from the west side of the main portion of the building. Figure 3 shows the building floor plan developed during the ANL inspection. Figure 4 provides photographs of the building exterior. 


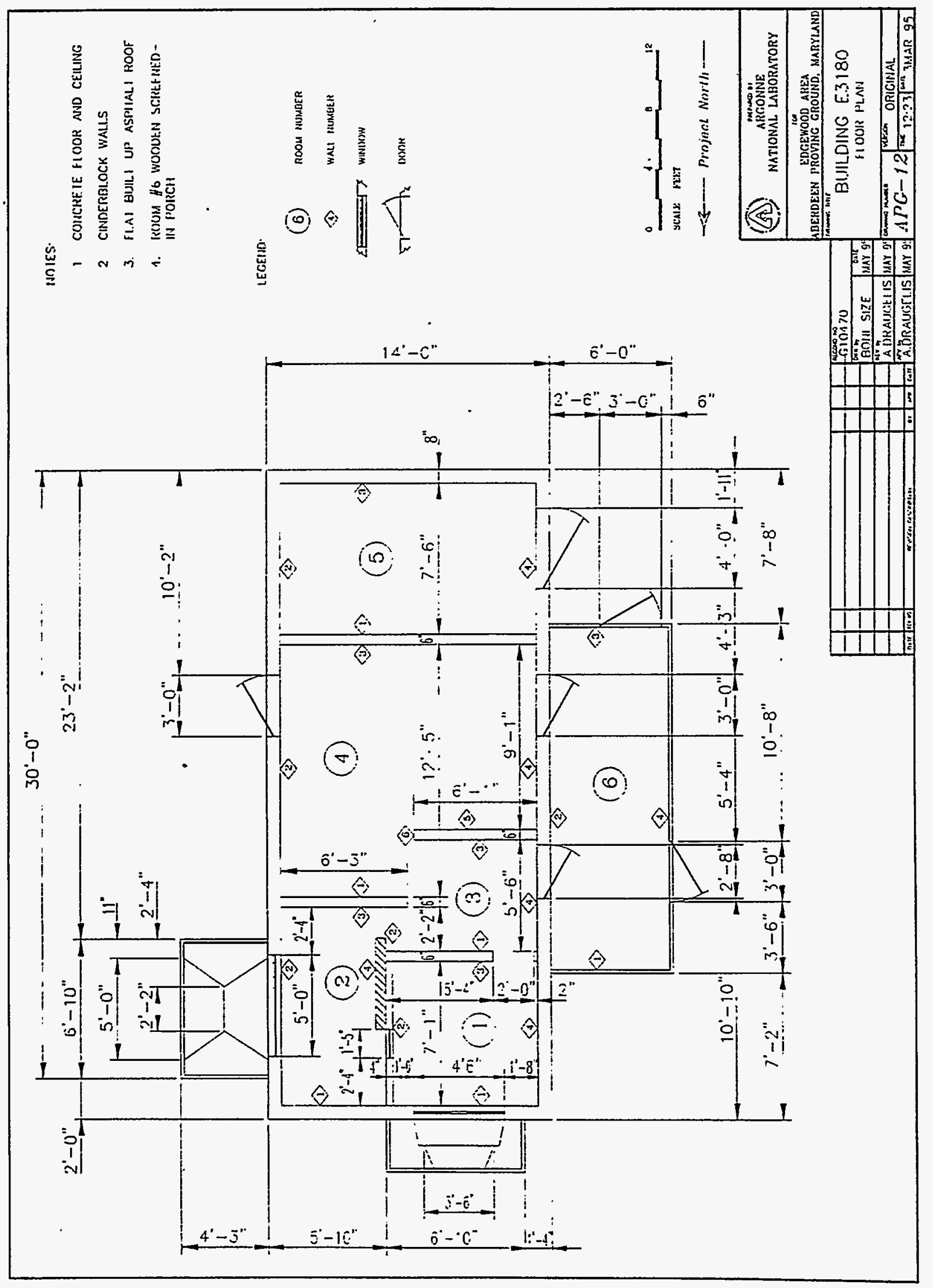

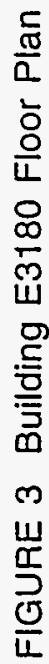



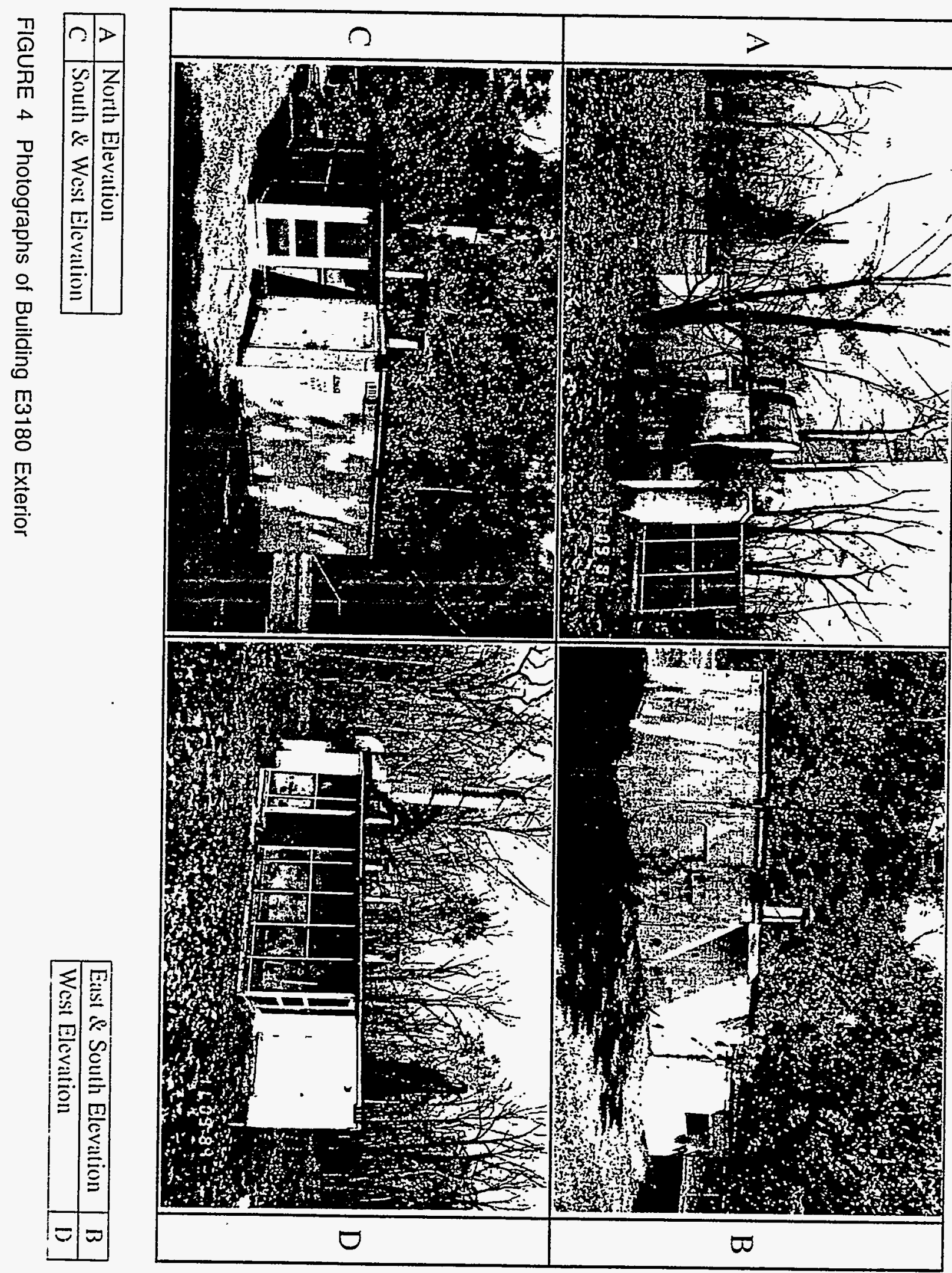


\subsubsection{Exterior Dimensions}

The exterior dimensions of the main portion of the building are $32 \mathrm{ft}$ long by $14 \mathrm{ft}$ wide by about $7 \mathrm{ft}$ high. Dimensions of the east pillbox extension are $6 \mathrm{ft} 10 \mathrm{in}$.. long by $4 \mathrm{ft} 3$ in. wide by $5 \mathrm{ft} 8 \mathrm{in}$. high. The ventilation system extension measures $6 \mathrm{ft} 10$ in. long by $3 \mathrm{ft} 9 \mathrm{in}$. wide and $5 \mathrm{ft} 8 \mathrm{in}$. high. The exterior dimensions of the porch are $17 \mathrm{ft} 2$ in. long, $6 \mathrm{ft}$ wide, and about $7 \mathrm{ft} \mathrm{high} \mathrm{(Figure} \mathrm{3).}$

\subsubsection{Topography}

The area surrounding the building is flat.

\subsubsection{Vegetation in the Immediate Vicinity}

The building is surrounded by cut vegetation (lawn) with lone trees near the northeast and northwest corners of the building. Vines are growing around the ventilation system extension on the north wall of the building (Figure 4A).

\subsubsection{External Aboveground Structures or Equipment}

The sheet-metal stack for the open (squirrel cage) ventilation system is attached to the north wall of the building. Electrical service lines and electrical conduits are attached to the east side of the building. A pole with a red and blue light at the top extends about $3 \mathrm{ft}$ above the roof near the south end of the east side of the building.

\subsubsection{Connections with Adjacent Buildings}

None.

\subsubsection{Underground Structures}

None. 


\subsubsection{Surface Drainage System}

None.

\subsubsection{Utility Access Points}

None.

\subsubsection{Exterior Piping}

None.

\subsubsection{Nearby Roads and Sidewalks}

Kings Creek Road is approximately $25 \mathrm{ft}$ south of the building.

\subsection{North Exterior Elevation}

\subsubsection{Dimensions}

The north exterior wall of the main portion of the building is $14 \mathrm{ft}$ long and about $7 \mathrm{ft}$ high. The ventilation system extension is $6 \mathrm{ft} 10 \mathrm{in}$. long, extends from the main building wall $3 \mathrm{ft} 9$ in., and is $5 \mathrm{ft} 8$ in. high (Figure 3 and 4).

\subsubsection{Construction Materials}

The exterior walls of the of the main portion building and ventilation system extension are 8 in. thick cinder block.

\subsubsection{Doors and Windows}

None. 


\subsubsection{Piping}

None.

\subsubsection{Utility Connections}

None.

\subsubsection{External Equipment or Structures}

The open (squirrel cage) ventilation system is attached to the north exterior of the building. The sheet-metal stack of the ventilation system extends approximately $15 \mathrm{ft}$ above the roof.

\subsubsection{Vegetation}

The area north of the building is cut vegetation (lawn) with lone trees near the northeast and northwest corners of the building. Vines are growing around the ventilation system on the north wall of the building.

\subsubsection{Overall Condition}

The north side of the building is in good condition, but shows signs of weathering. The sheet metal stack of the ventilation system is rusted.

\subsection{East Exterior Elevation}

\subsubsection{Dimensions}

The east elevation of the building is $32 \mathrm{ft}$ long and about $7 \mathrm{ft}$ high. The pillbox extension is $6 \mathrm{ft} 10 \mathrm{in}$. long, extends $4 \mathrm{ft} 3$ in. out from the main building wall, and is $5 \mathrm{ft} 8 \mathrm{in}$. high (Figures 3 and 4). 


\subsubsection{Construction Materials}

The exterior wall and pillbox extension are constructed of 8-in.-thick cinder blocks.

\subsubsection{Doors and Windows}

One 3-ft-wide by 7-ft-long metal door is located $10 \mathrm{ft} 2 \mathrm{in}$. from the southeast corner of the east side of the building. The sealed, rectangular pillbox opening, measuring $5 \mathrm{ft}$ wide and tapering to $2 \mathrm{ft} 2 \mathrm{in}$., is $2 \mathrm{ft} 11 \mathrm{in}$. from the northeast corner of the building. There are no windows on the east elevation of the building.

\subsubsection{Piping}

None.

\subsubsection{Utility Connections}

Two electrical power lines are connected to the east elevation of the building; one is attached at the roof line and the second is attached to a pipe extending approximately $3 \mathrm{ft}$ above the roof. Electrical conduits are attached to, and enter, the east exterior elevation of the building.

\subsubsection{External Equipment or Structures}

A pole with a red and blue light at the top extends about $3 \mathrm{ft}$ above the roof near the south end of the east side of the building.

\subsubsection{Vegetation}

The area east of the building is covered by cut vegetation (lawn).

\subsubsection{Overall Condition}

The east elevation of the building is in good condition, but shows signs of weathering. The electrical conduits are rusted. 


\subsection{South Exterior Elevation}

\subsubsection{Dimensions}

The south exterior wall of main portion of the building measures $14 \mathrm{ft}$ long and about $7 \mathrm{ft}$ high. The porch on the west side of the building is $6 \mathrm{ft}$ in wide and about $7 \mathrm{ft}$ high (Figures 3 and 4).

\subsubsection{Construction Materials}

The south exterior wall of the main portion building is constructed of 8-in.-thick cinder blocks. The porch has a fine wire-mesh screen wall that extends from the roof to the floor and is supported by wood framing.

\subsubsection{Doors and Windows}

No doors or windows are located in the south exterior wall of the main portion of the building. A 3-ft-wide screen door is located near the west corner of the south wall of the porch.

\subsubsection{Piping}

None.

\subsubsection{Utility Connections}

None.

\subsubsection{External Equipment or Structures}

None. 


\subsubsection{Vegetation}

The area south of the building is cut vegetation (lawn)

\subsubsection{Overall Condition}

The south exterior wall of the building is in good condition.

\subsection{West Exterior Elevation}

\subsubsection{Dimensions}

The west exterior wall of the main portion of the building is $32 \mathrm{ft}$ long and about $7 \mathrm{ft}$ high. The porch, located in the approximate center of the west wall of the main portion of the building, is $17 \mathrm{ft} 2$ in. long and about $7 \mathrm{ft}$ high (Figures 3 and 4).

\subsubsection{Construction Materials}

The west exterior wall of the main portion of the building is constructed of 8 -in.-thick cinder blocks. The porch has a fine wire-mesh screen wall that extends from the roof to the floor and is supported by wood framing.

\subsubsection{Doors and Windows}

Two doorways occupy the west exterior wall of the building. The first, which contains no door, measures $2 \mathrm{ft} 8 \mathrm{in}$. wide and is located $3 \mathrm{ft} 6 \mathrm{in}$. from the northwest corner of the porch. The second doorway, with a metal door, is $4 \mathrm{ft}$ wide and located about $2 \mathrm{ft}$ from the southeast corner of the west exterior wall. The metal door of the second doorway was sealed at the time of the ANL inspection. There are no windows in the west elevation.

\subsubsection{Piping}

None. 


\subsubsection{Utility Connections}

None.

\subsubsection{External Equipment or Structures}

None.

\subsubsection{Vegetation}

The area west of the building is covered by cut vegetation (lawn).

\subsubsection{Overall Condition}

The west elevation of the building is in good condition, but shows signs of weathering. There is no door in the porch doorway.

\subsection{Roof}

\subsubsection{Type and Dimensions}

The building has a flat roof. The roof of the main portion of building is $14 \mathrm{ft}$ wide by $32 \mathrm{ft}$ long; the porch roof is $17 \mathrm{ft} 2 \mathrm{in}$. long by $6 \mathrm{ft}$ wide; the pillbox extension roof is $6 \mathrm{ft} 10 \mathrm{in}$. long by $4 \mathrm{ft} 3 \mathrm{in}$. wide; and the ventilation system extension roof is $6 \mathrm{ft} 10 \mathrm{in}$. long by $3 \mathrm{ft} 9 \mathrm{in}$. wide (Figures 3 and 4)

\subsubsection{Height}

The height of the roof is about $7 \mathrm{ft}$. 


\subsubsection{Surface Materials}

The main portion of the building and the extensions have a built-up asphalt roof; the porch roof has an asphalt finish.

\subsubsection{Support System}

The roof on the main portion of the building and extensions is concrete supported by the exterior and interior walls. The porch roof is wood supported by wood rafters.

\subsubsection{Condition}

The roof of the building appeared to be in good condition.

\subsubsection{Equipment Located on Roof}

None.

\subsubsection{Chimneys, Roof Vents, or Vent Stacks}

Four sheet-metal vents extend approximately $2 \mathrm{ft}$ above the roof of the building.

\subsubsection{Piping}

None. 


\subsection{Interior Floor Plan}

\subsubsection{Room Numbers and Dimensions}

The main portion of the building contains five rooms. The dimensions of the individual rooms are listed below:

- Room 1: about $8 \mathrm{ft}$ long by $7 \mathrm{ft}$ wide;

- Room 2: about $9 \mathrm{ft} 8$ in. long by $5 \mathrm{ft}$ wide;

- Room 3: $6 \mathrm{ft}$ long by $5 \mathrm{ft} 6$ in. wide; and

- $\quad$ Room 4: $12 \mathrm{ft} 4$ in. long by. $9 \mathrm{ft}$ wide.

The dimensions of room 5 , determined by exterior measurements, are assumed to be approximately $7 \mathrm{ft} 6 \mathrm{in}$. wide by $12 \mathrm{ft} 8 \mathrm{in}$. long. The porch, room 6 , is $6 \mathrm{ft}$ wide by $17 \mathrm{ft}$ long. Figure 3 shows the floor plan of the building, developed during the ANL investigation.

\subsubsection{Walls}

The exterior walls of the main portion of the building (rooms 1 through 4) are whitepainted, 8-in.-thick cinder blocks. The interior walls are white-painted, 4-in.- or 6-in.-thick cinder blocks. The exterior porch walls (room 6) are fine wire-mesh screen that extends from the roof to the floor and is supported by wood framing. The interior wall of the porch (room 6) is constructed of 8-in.-thick cinder blocks.

\subsubsection{Floor}

The floors of the main portion of the building (rooms 1 through 4) are concrete. The floor of the porch (room 6) is wood. Access to room 5 was prohibited, so the composition of the floor is unknown. 


\subsubsection{Floor Penetrations}

No floor penetrations were noted in rooms 1 through 4 or room 6 . Access to room 5 was prohibited, so floor penetrations could not be determined.

\subsubsection{Interior Partitions}

The interior walls or partitions are 6-in.-thick or 4-in.-thick painted cinder blocks.

\subsubsection{Equipment or Supplies}

Several electric heaters and fire blanket holders were observed in the building at the time of the ANL inspection. A small bench is attached to the corner of walls 1 and 2 in room 2 .

\subsection{Room 1}

\subsubsection{Walls}

Walls 1 and 4 are constructed of 8-in.-thick cinder blocks. Wall 2 is 4 -in.-thick cinder blocks, and wall 3 is 6 -in.-thick cinder blocks. Figure 3 shows the assigned wall numbers. Photographs of the interior walls of room 1 are shown in Figure 5.

\subsubsection{Finish Materials}

The cinder block walls are painted white.

\subsubsection{Piping}

None. 


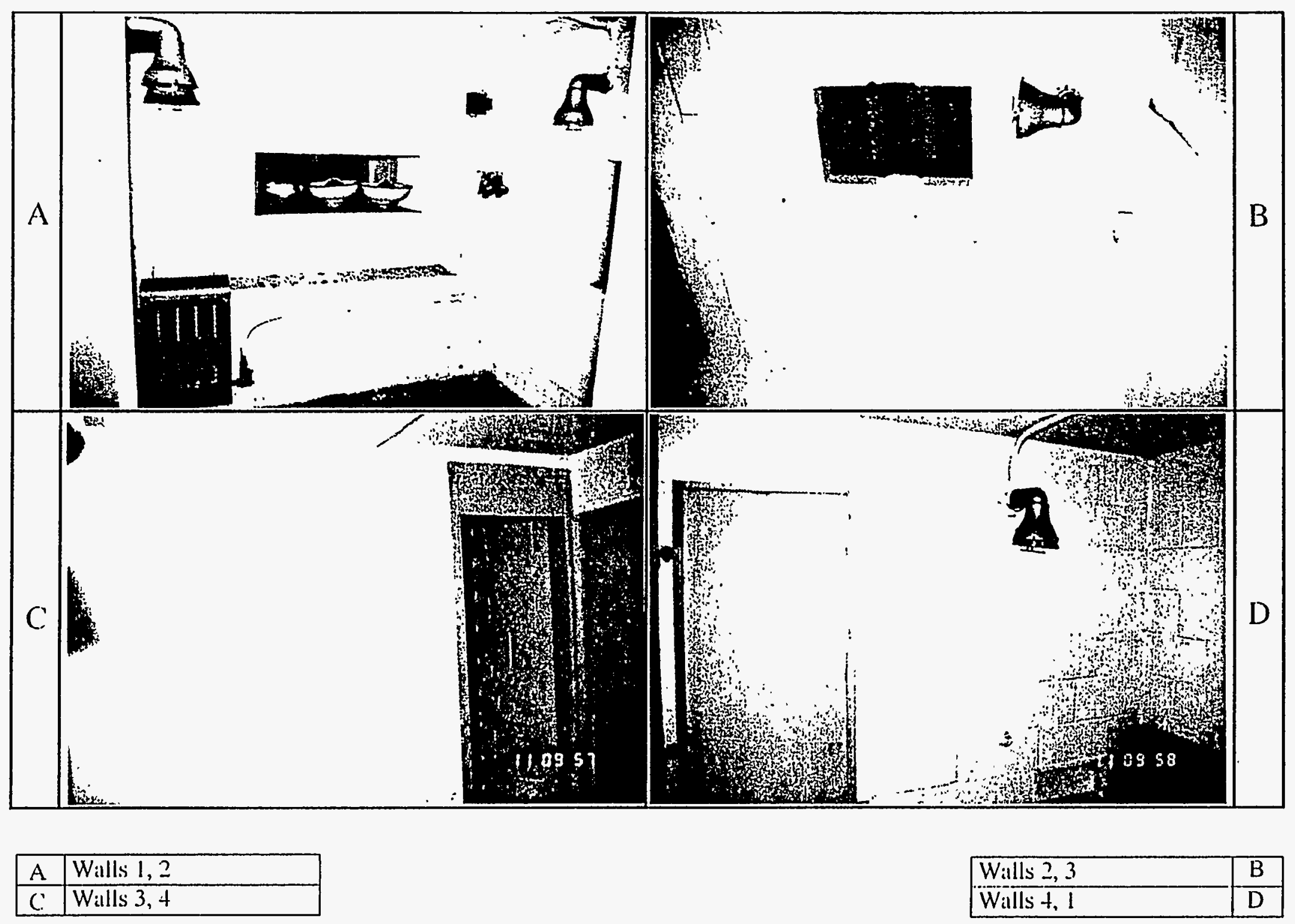

FIGURE 5 Photographs of Room 1 - Walls 


\subsubsection{Equipment}

An electric heater, lighting fixtures, electrical conduits, and high-voltage power outlets are attached to the walls of room 1 .

\subsubsection{Doors and Windows}

Wall 1 contains the ventilation system opening, which measures about $4 \mathrm{ft} 6$ in. wide by $3 \mathrm{ft}$ high. Wall 2 has an interior window into room 2, about $1 \mathrm{ft} 5 \mathrm{in}$. wide by $2 \mathrm{ft}$ high. Wall 3 has a 2 -ft-wide by $6 \mathrm{ft}$ high doorway with a metal door in the southwest corner. The door leads into room 3 .

\subsubsection{Ceiling}

The ceiling is concrete, painted white, and contains an opening that leads to an exterior sheet-metal vent on the roof of the building. A sealed pipe and numerous indentations were observed in the ceiling. There are also electrical conduits attached to the ceiling (Figure 6A).

\subsubsection{Floor}

The floor in room 1 is concrete (Figure 6B).

\subsection{Room 2}

\subsubsection{Walls}

Walls 1 and 2 are constructed of 8-in.-thick cinder blocks; walls 3 and 4 are 6-in.-thick cinder blocks. Figure 3 shows the assigned wall numbers. Photographs of the interior walls of room 2 are shown in Figure 7.

\subsubsection{Finish Materials}

The cinder block walls are painted white. 

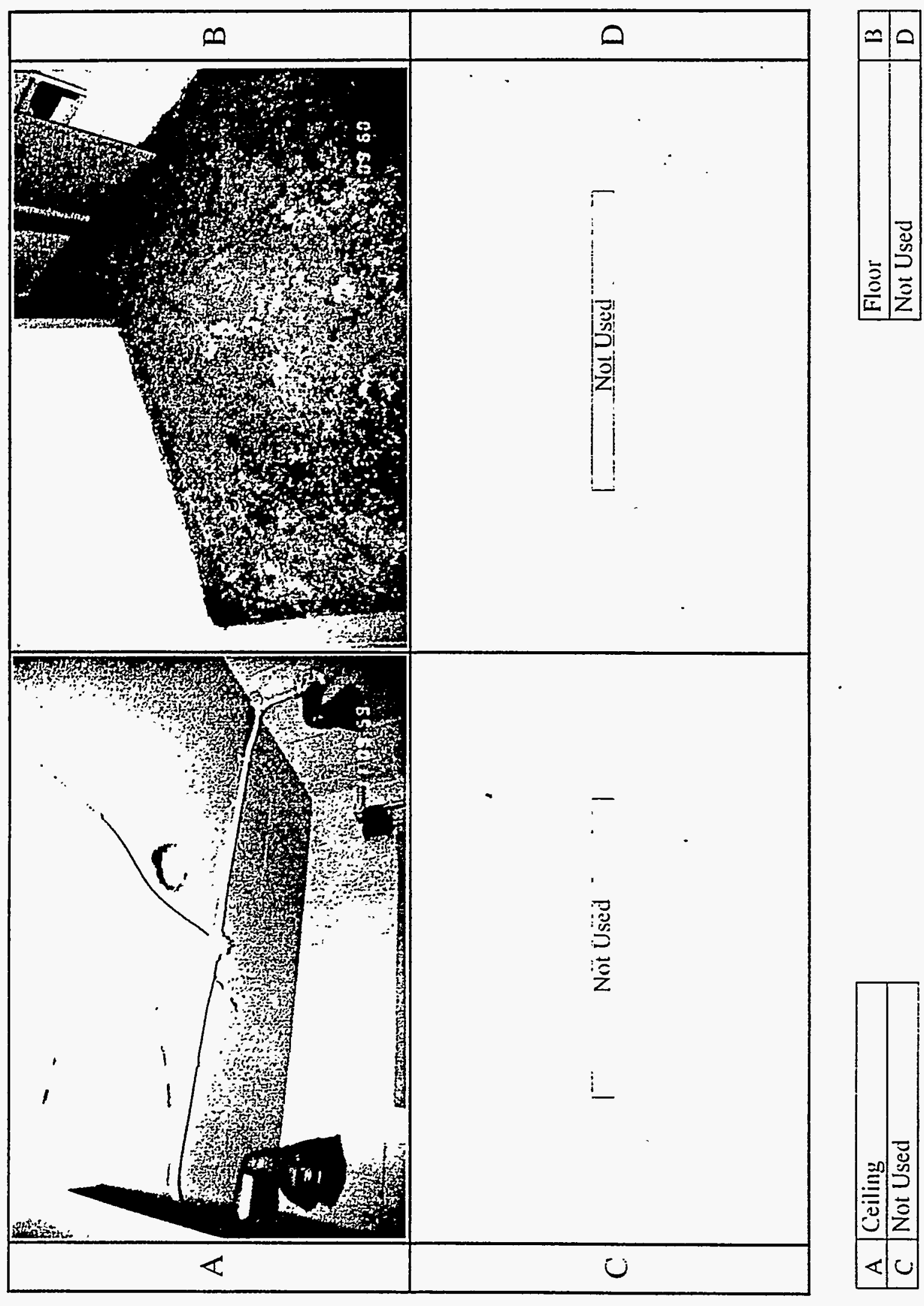

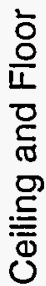

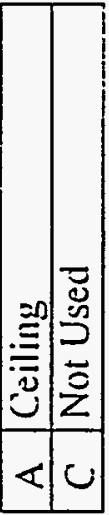

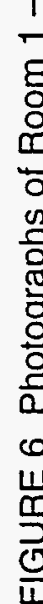




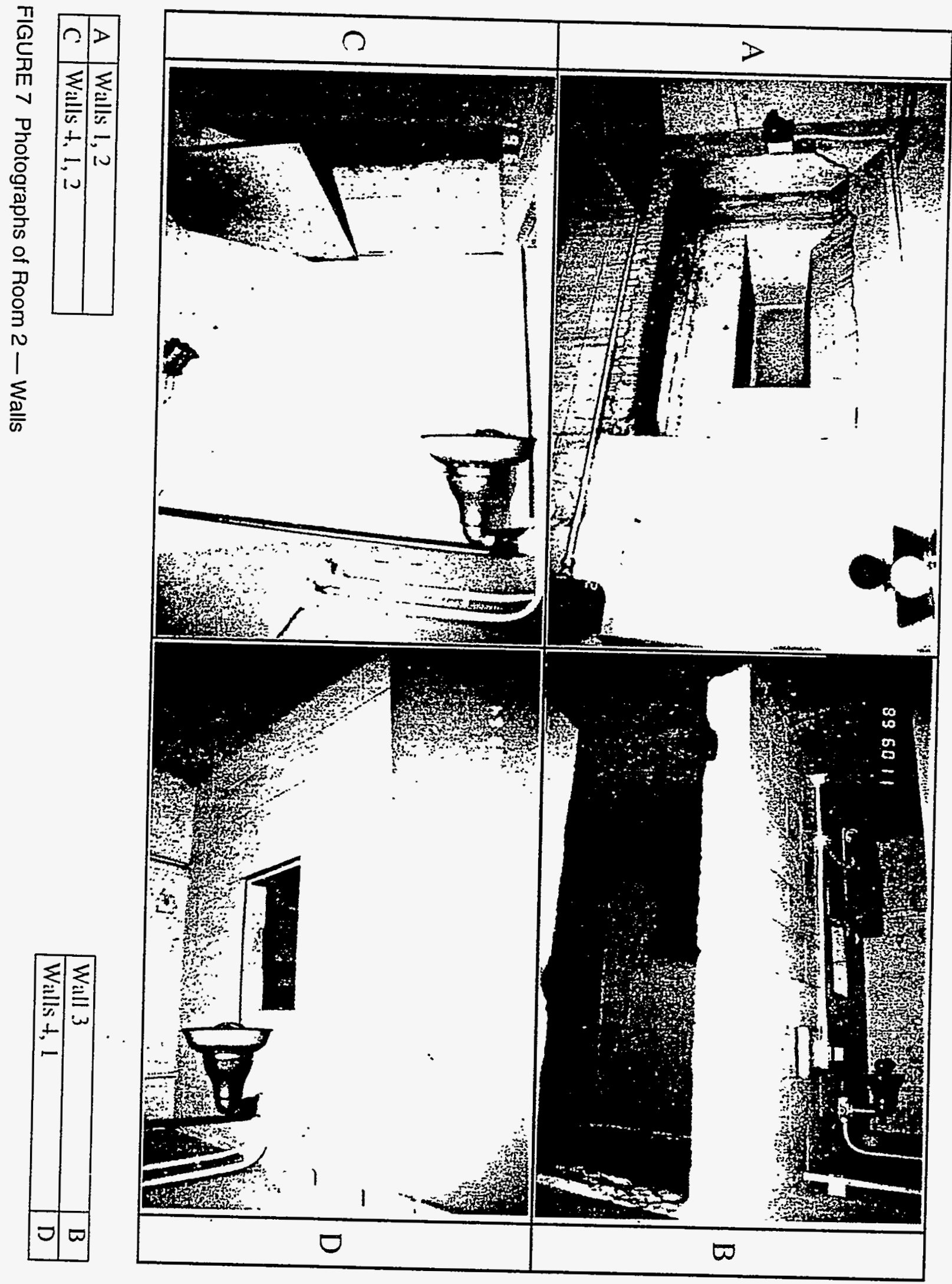




\subsubsection{Piping}

None.

\subsubsection{Equipment}

An electric heater, lighting fixtures, electrical conduits, and high-voltage power outlets are attached to the walls and ceiling of room 2 . A small bench is attached to walls 1 and 2 .

\subsubsection{Doors and Windows}

Wall 2 contains the sealed pillbox opening that measures about $5 \mathrm{ft}$ wide by $3 \mathrm{ft}$ high and tapers to about $2 \mathrm{ft}$ by $1 \mathrm{ft}$. Wall 3 has two interior windows leading to room 4: one measures about $18 \mathrm{in}$. square and the other about $8 \mathrm{in}$. by $4 \mathrm{in}$. A doorway measuring $2 \mathrm{ft} 2 \mathrm{in}$. wide with a sliding metal door in the southwest corner leads into room 3 . Wall 4 also contains an interior window into room 1 that measures about $1 \mathrm{ft} 5 \mathrm{in}$. wide by $2 \mathrm{ft}$ high.

\subsubsection{Ceiling}

The ceiling is concrete, painted white, and has an opening that leads to an exterior sheetmetal vent on the roof of the building. Two sealed pipes and numerous indentations were observed in the ceiling. Electrical conduits and hardware for the sliding door are also attached to the ceiling (Figure 8A).

\subsubsection{Floor}

The floor in room 2 is concrete (Figure $8 B$ ). 


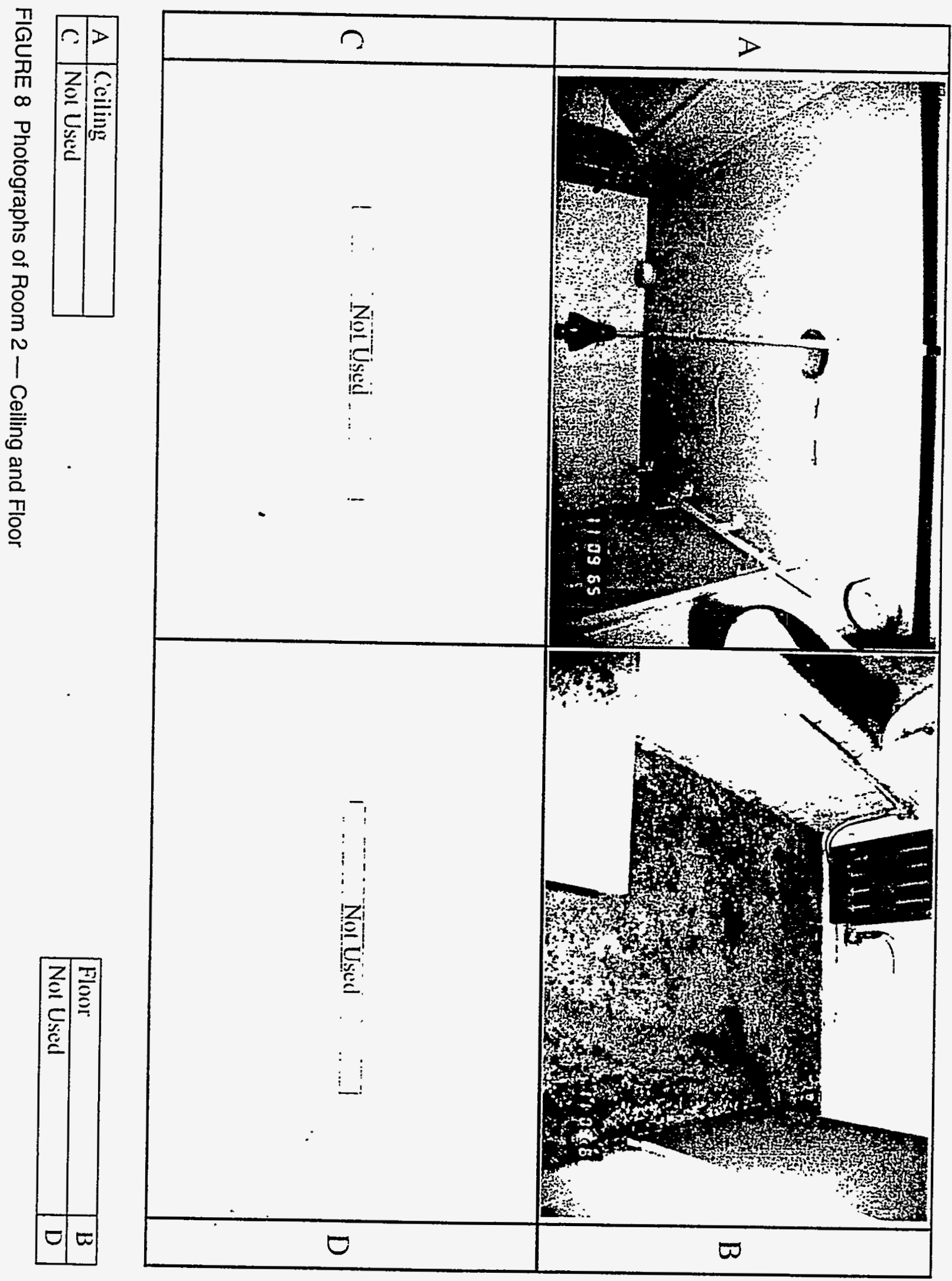




\subsection{Room 3}

\subsubsection{Walls}

Walls 1 and 3 are constructed of 6 -in.-thick cinder blocks; wall 4 is 8 -in.-thick cinder blocks. Wall 2 consist of two doorways and the end of the 6-in.-thick cinder block wall dividing rooms 2 and 4 . Figure 3 shows assigned wall numbers. Photographs of the interior walls of room 3 are shown in Figure 9.

\subsubsection{Finish Materials}

The cinder block walls are painted white.

\subsubsection{Piping}

None.

\subsubsection{Equipment}

Electrical conduits are attached to the walls and ceiling of room 3.

\subsubsection{Doors and Windows}

A 2-ft-wide by 6-ft-high doorway, containing a metal door, in the northwest comer of wall 1 leads into room 1 . Wall 2 consist of two doorways, with no doors, and the end of the 6-in.thick cinder block wall dividing rooms 2 and 4 . The doorway into room 2 is $2 \mathrm{ft} 2 \mathrm{in}$. wide. The doorway into room 4 is $2 \mathrm{ft} 10 \mathrm{in}$. wide. Wall 4 contains a 2 -ft-8-in.-wide doorway with a metal door leading onto the porch (room 6). Room 3 has no windows.

\subsubsection{Ceiling}

The ceiling is concrete, painted white, and has an opening that leads to an exterior sheetmetal vent on the roof of the building. Numerous indentations were observed in the ceiling and several electrical conduits are attached to the ceiling (Figure 10A). 

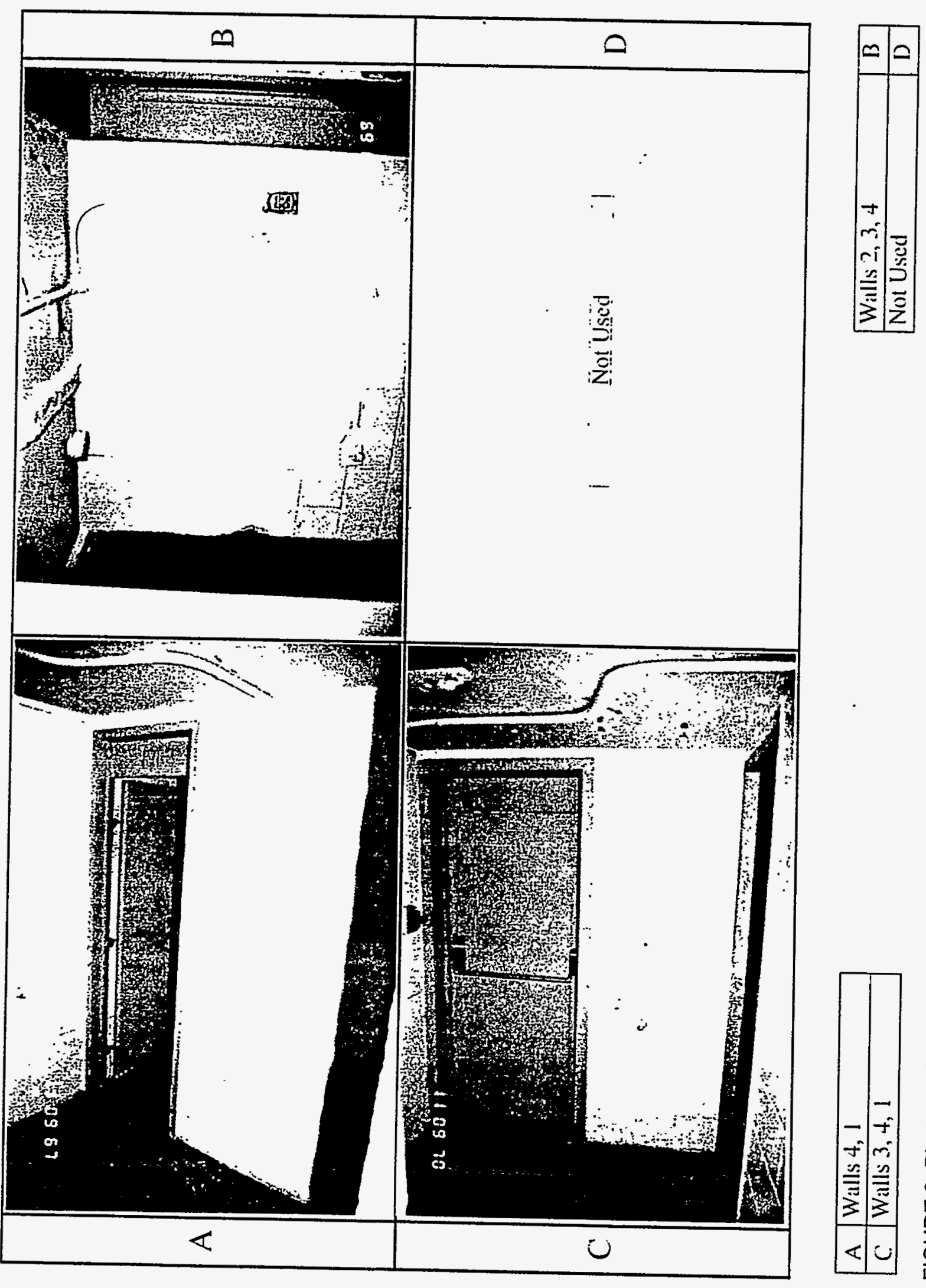

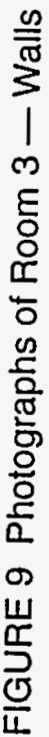



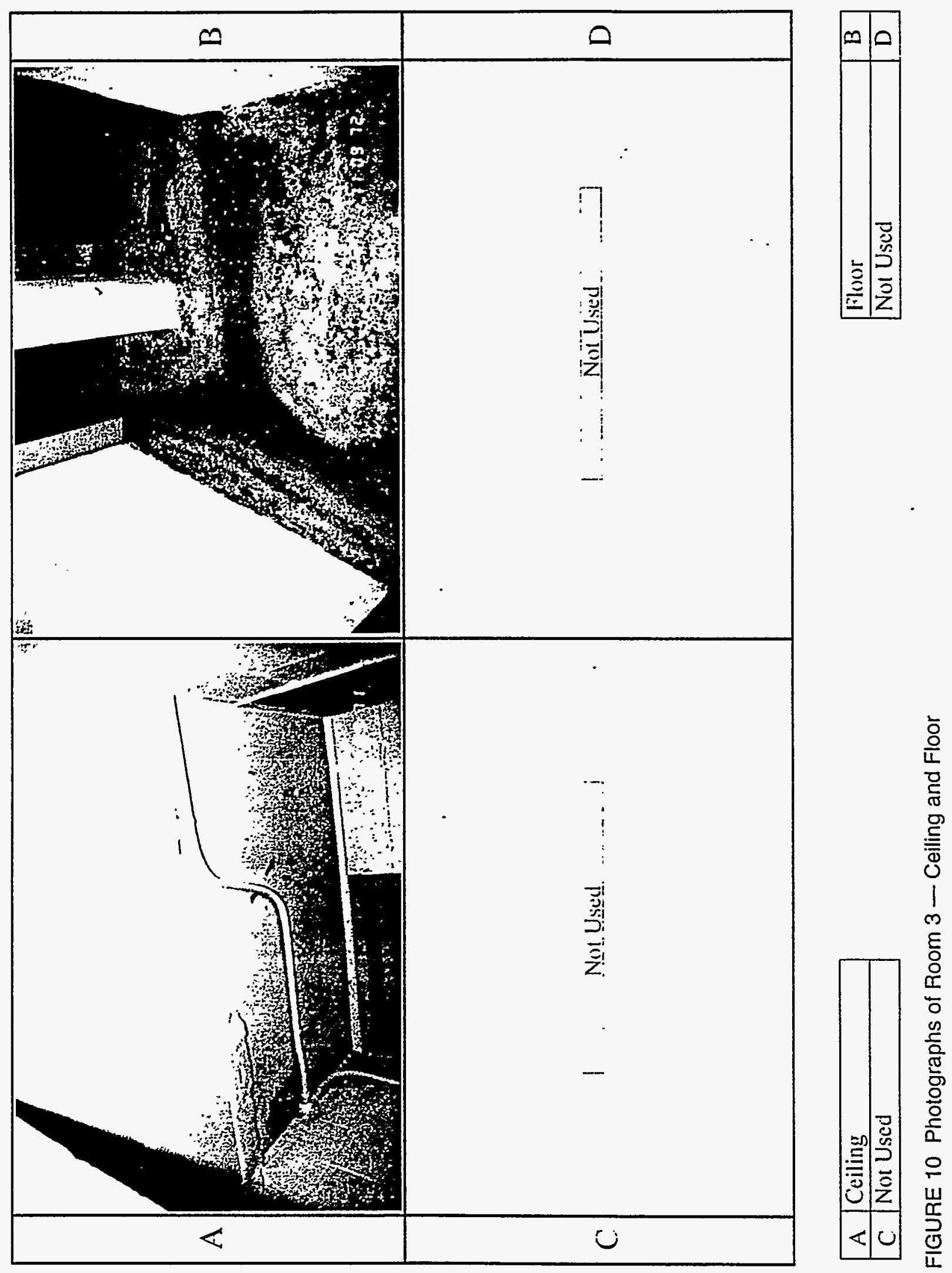


\subsubsection{Floor}

The floor in room 3 is concrete (Figure 10B).

\subsection{Room 4}

\subsubsection{Walls}

Walls 1, 3, and 5 are constructed of 6-in.-thick cinder blocks; walls 2 and 4 are 8-in.-thick cinder blocks. Figure 3 shows the assigned wall numbers. Photographs of the interior walls of room 4 are shown in Figure 11.

\subsubsection{Finish Materials}

The cinder block walls are painted white.

\subsubsection{Piping}

None.

\subsubsection{Equipment}

Two electric heaters, lighting fixtures, electrical conduits, high-voltage power outlets, and a fire blanket holder are attached to the walls and ceiling of room 4 .

\subsubsection{Doors and Windows}

Room 4 has three doorways and two interior windows. One doorway, measuring $2 \mathrm{ft}$ 10 in. wide and containing no door, is located between walls 1 and 5 and leads into room 3 . A 3-ft-wide doorway in wall 2, with a metal door, leads to the building exterior. A second 3-ft-wide doorway in wall.4, with a metal door, leads to the porch (room 6). Wall 2 has two interior windows into room 2: one measures about 18 in. square and the second measures about 8 in. by 4 in. 

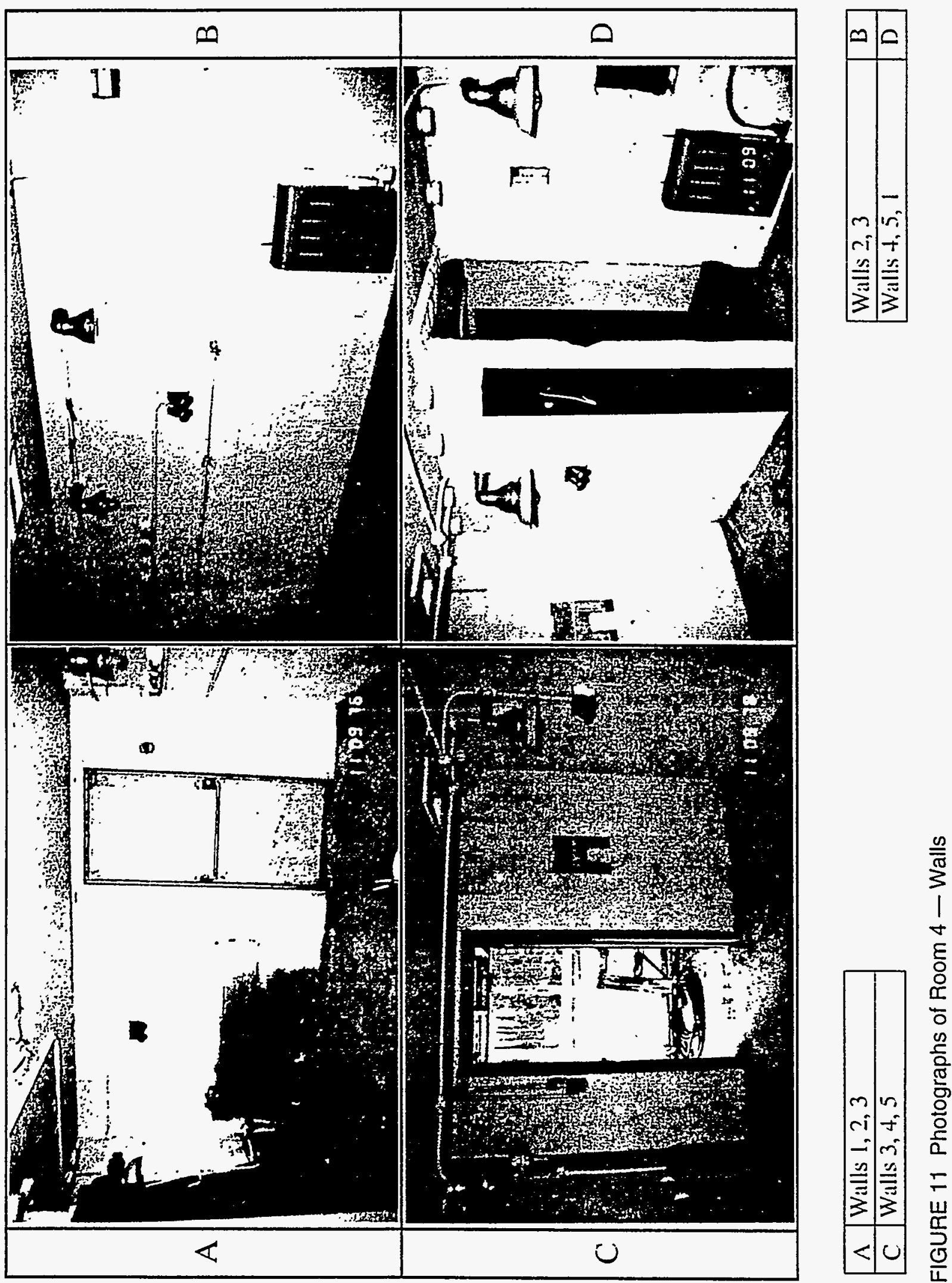


\subsubsection{Ceiling}

The ceiling is concrete painted white. There are four rectangular hatches and eight sealed pipes in the ceiling. Electrical conduits also are attached to the ceiling (Figure 12A).

\subsubsection{Floor}

The floor in room 4 is concrete (Figure 12B).

\subsection{Room 5}

No interior inspection was conducted and no photographs were taken of room 5 because this room was sealed.

\subsubsection{Walls}

On the basis of an exterior examination and measurements, wall 1 is assumed to be constructed of 6-in.-thick cinder blocks; walls 2, 3, and 4 are 8-in.-thick cinder blocks.

\subsubsection{Finish Materials}

Unknown.

\subsubsection{Piping}

Unknown.

\subsubsection{Equipment}

Unknown. 

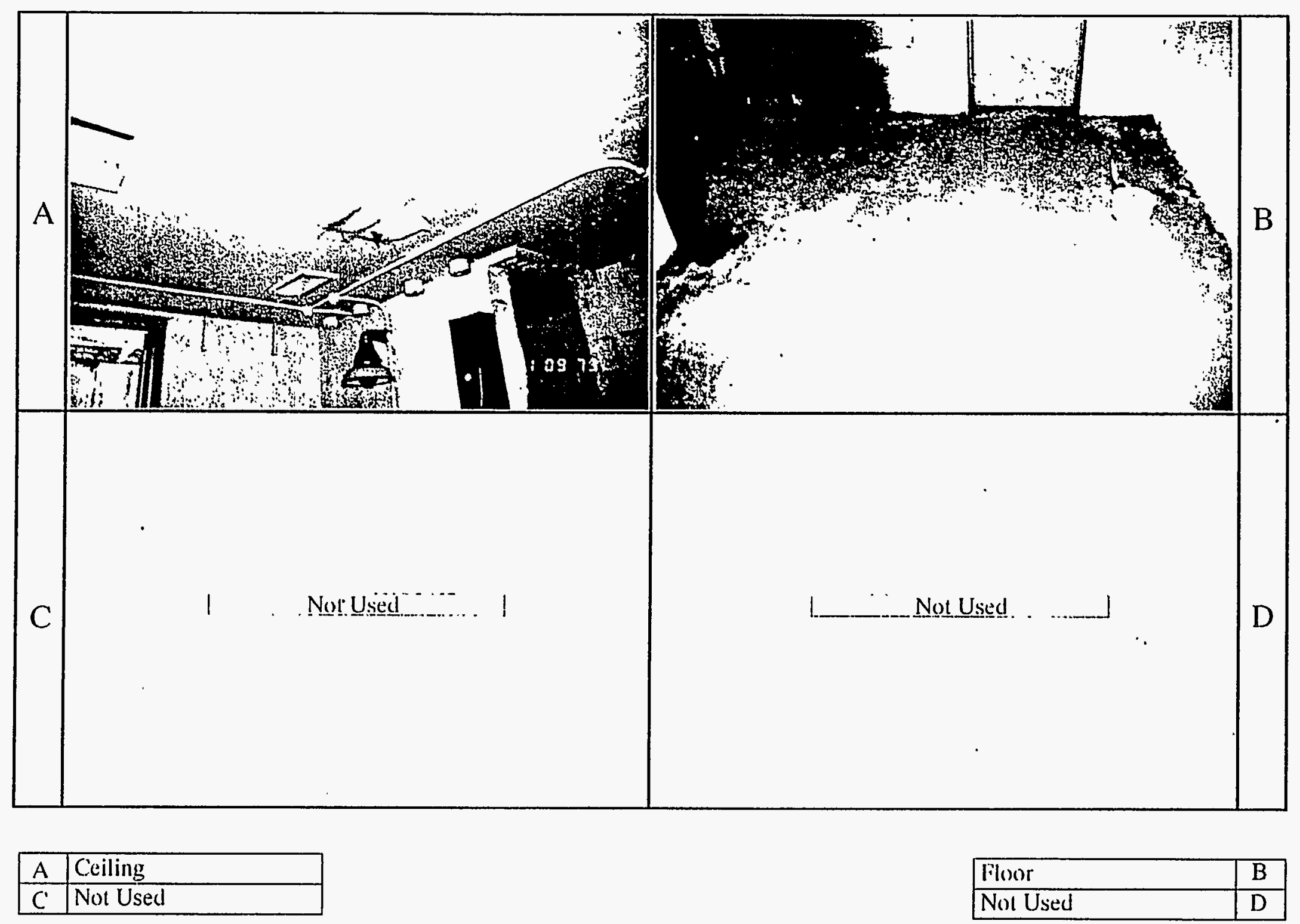

\begin{tabular}{|l|c|}
\hline Floor & B \\
\hline Not Used & D \\
\hline
\end{tabular}

FIGURE 12 Photographs of Room 4-Ceiling and Floor 


\subsubsection{Doors and Windows}

Based on an exterior examination, room 5 has no windows. One 4-ft-wide doorway with a metal door on the west wall leads to the building exterior. This door was sealed during the ANL investigation.

\subsubsection{Ceiling}

Unknown.

\subsubsection{Floor}

Unknown.

\subsection{Room 6}

\subsubsection{Walls}

Walls 1,3 , and 4 consist of a fine wire-mesh screen that extends from the roof to the floor and is supported by wood framing. Wall 2 is constructed of 8 -in.-thick cinder blocks. Figure 3 shows assigned wall numbers. No photographs of the interior walls of room 6 were taken during the inspection.

\subsubsection{Finish Materials}

The cinder block wall (wall 1) and the wood framing supporting the screen walls are painted white.

\subsubsection{Piping}

None. 


\subsubsection{Equipment}

None.

\subsubsection{Doors and Windows}

Room 6 has two doorways leading to interior rooms and two doorways to the exterior. Wall 2 contains two 6-ft-high doorways with metal doors; a doorway measuring $2 \mathrm{ft} 8 \mathrm{in}$. wide and located $3 \mathrm{ft} 6$ in. from wall 1 leads into room 3, and a 3-ft-wide doorway located $2 \mathrm{ft} 4 \mathrm{in}$. from wall 3 leads into room 4 . Wall 3 contains a 3 -ft-wide doorway with a screen door that is located $2 \mathrm{ft} 6$ in. from wall 2 and leads to the exterior. Wall 4 has a 3 -ft-wide doorway (with no door) that is located $2 \mathrm{ft} 6$ in. from wall 1 and leads to the building exterior.

\subsubsection{Ceiling}

The ceiling is wood, painted white, supported by wood rafters.

\subsubsection{Floor}

The floor in room 6 is wood (Figure 8B). 


\section{Geophysical Investigation}

ANL geophysical staff surveyed the area around Building E3180 during late June and early July 1994. Nonintrusive methods used for the surveys were magnetic gradiometer, totalfield magnetics, electrical conductivity (EM-31), induced electromagnetic field (EM-61), and GPR.

Geophysical surveys of the Building E3180 site suggest that large metallic objects may be buried between the building and the southern edge of the survey area (Kings Creek Road), and immediately adjacent to the building on the east, north, and west sides. Elsewhere around the site, buried metallic objects are probably limited in size. GPR data indicate that the ground within $35 \mathrm{ft}$ of the building has been disturbed. GPR data also show a north/south-trending anomaly about $10 \mathrm{ft}$ west of the west side of the building that is apparently caused by a nonmetallic source.

The geophysical surveys suggest the presence of some underground objects near Building E3180, but do not provide conclusive evidence of the sources of the anomalies detected. The interim geophysical report for Building E3180 is provided as Appendix A. 


\section{Air Quality Investigation}

ANL staff collected air quality samples downwind and inside of Building E3180 during November 1994. Analytical results showed no distinguishable difference in the levels of hydrocarbons and chlorinated solvents between the two background samples and the samples taken inside Building E3180. These results indicate that Building E3180 is not a source of volatile organic compound contamination. The air quality monitoring report is provided in Appendix B. Because room 5 could not be investigated, an inspection and monitoring of that room is recommended. 


\section{Underground Storage Tanks}

No information on underground storage tanks associated with Building E3180 is available. 


\section{Conclusions}

On the basis of information collected and reviewed by ANL for Building E3180, it is the authors' judgment that potential undetermined contamination could exist in room 5 of the building. No significant air contamination is associated with the other rooms the building. Results of the geophysical surveys indicate some anomalies near Building E3180 that warrant further investigation and evaluation. 


\section{References}

EAI Corporation, 1989, Historical Records Search and Site Survey of the Edgewood Area Building - Final Report, prepared for U.S. Army Chemical Researçh, Development, and Engineering Center, Aberdeen Proving Ground, Maryland, under contract no. DAAIS-87-D0021.

Nemeth, G., 1989, RCRA Facility Assessment Report, Edgewood Area, Aberdeen Proving Ground, Maryland, unnumbered report prepared for Aberdeen Proving Ground, Maryland. 
Appendix A:

Interim Progress Report -

Environmental Geophysics:

Building E3180 Decommissioning, Aberdeen Proving Ground 


\section{Interim Progress Report - \\ Environmental Geophysics: \\ Building E3180 Decommissioning, Aberdeen Proving Ground}

by

M.D. Thompson, C.R. Daudt, L.D. McGinnis, S.F. Miller, M.A. Benson, C.A. Padar, and M.A. Glennon

Center for Environmental Restoration Systems

Energy Systems Division

Argonne National Laboratory

9700 South Cass Avenue

Argonne, Illinois 60439

March 1995

Work sponsored by

United States Department of Defense, United States Army, Aberdeen Proving Ground, Maryland 


\section{Preface}

This report is one of a series on environmental geophysical studies around perimeters of buildings in the Edgewood Area of Aberdeen Proving Ground. The series was initiated in 1991 at Building E5032, where techniques were evaluated and a design for the surveys was established. Studies continued in 1992 and 1993, when surveys of Buildings E5190, E5282, E5375, E5440, E5476, E5481, E5485, E5487, E5489, E5974, E5978, and the Building E103 Dump were completed. In 1994, geophysical surveys were completed around Buildings E1489, E2370, E3162, E3163, E3180, E3236, E3613, E3640, E6891, and E7995, and Building E5032 was resurveyed; newer, continuously recording equipment was used in all 1994 surveys. Deeper insight into the magnetic, electrical, and radar imagery characteristics of the Canal Creek and Kings Creek Areas has been gained from the completion of each geophysical survey. Subsequent improvements in survey design and data acquisition, processing, and interpretation have been realized at more recent sites, including Building E3180. 


\section{Contents}

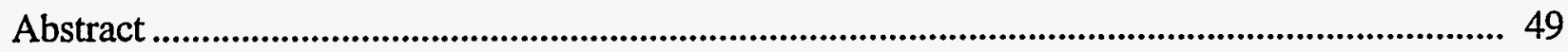

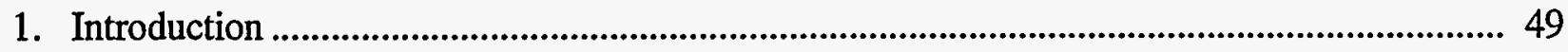

1.1 History of Building E3180 ....................................................................................... 51

1.2 Site Reconnaissance....................................................................................................... 52

1.3 Geology and Physiographic Setting................................................................................ 53

1.4 Surveys......................................................................................................................... 53

1.5 Survey Grid and Locations of Observations................................................................. 53

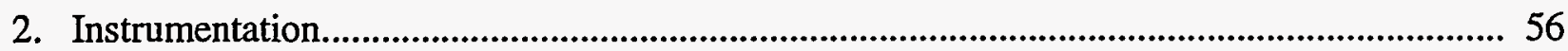

2.1 Magnetic Gradiometer and Cable Locator ..................................................................... 56

2.2 Total-Field Magnetics Meter G-822L .............................................................................. 56

2.3 Conductivity Meter EM-31 ....................................................................................... 57

2.4 Time-Domain Millivolt Meter EM-61 ..................................................................... 57

2.5 Ground-Penetrating-Radar System.............................................................................. 58

3. Geophysical Measurements and Surveys........................................................................... 59

3.1 Total-Field Magnetics.................................................................................................. 59

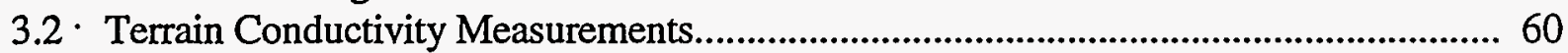

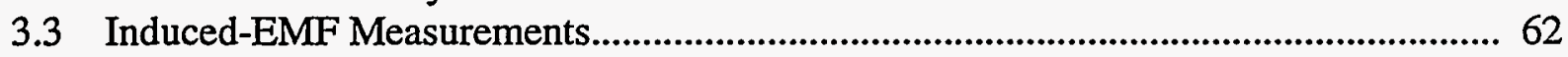

3.4 Ground-Penetrating-Radar Measurements ......................................................................... 63

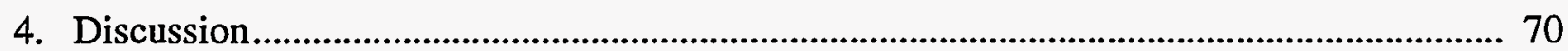

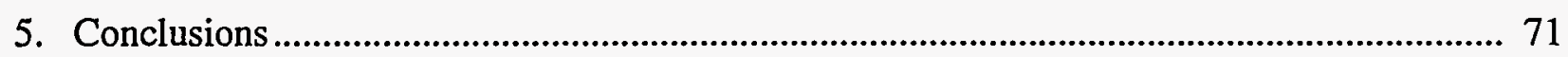

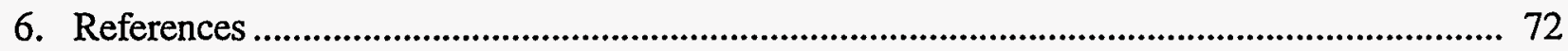

Attachment: Coordinates of Ground-Penetrating-Radar Profiles at Building E3180................... 75

\section{Table}

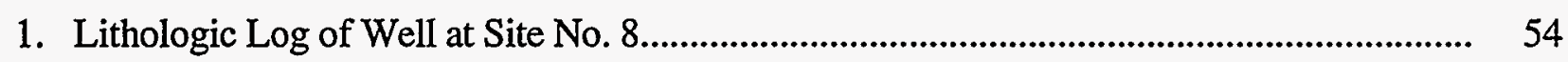




\section{Figures}

1. General Site Map of the Kings Creek Area, Aberdeen Proving Ground, Md

2. Detailed Location Map of Building E3180

3. Total Magnetic Field Anomaly Map

4. Terrain Conductivity Anomaly Map.

5. EMF Anomaly Map.

6. Locations of Anomalous GPR Reflectors for Building E3180

7. Two Adjacent West-to-East GPR Profiles on West Side of Building E3180 66

8. Two Adjacent West-to-East GPR Profiles on North Side of Building E3180 67

9. Two Nearly Adjacent West-to-East GPR Profiles on East Side of Building E3180. 68 


\title{
Interim Progress Report - \\ Environmental Geophysics: \\ Building E3180 Decommissioning, Aberdeen Proving Ground
}

\author{
by \\ M.D. Thompson, C.R. Daudt, L.D. McGinnis; S.F. Miller, \\ M.A. Benson, C.A. Padar, and M.A. Glennon
}

\begin{abstract}
The immediate vicinity of Building E3180, a potentially contaminated site in the Edgewood Area of Aberdeen Proving Ground, was examined by using several noninvasive geophysical methods, including total-field magnetic, electrical conductivity, time-domain electrical induction, and ground-penetrating-radar (GPR) techniques. Several point-source anomalies were observed in two or more data sets; the anomalies generally had radii of $5 \mathrm{ft}$ or less. Several data sets indicated strong anomalies adjacent to the building, which might be explained, in part, by buried metallic objects. GPR data were useful in delineating the extent of disturbed sediments. A linear trend in GPR reflection data at one location suggests the presence of a buried tile or similar nonmetallic linear feature.
\end{abstract}

\section{Introduction}

Aberdeen Proving Ground (APG), in the state of Maryland, is managing a comprehensive Installation Restoration Program involving more than 360 solid-waste-managing units contained within 13 study areas. The Edgewood Area of Aberdeen Proving Ground appears on the National Priority List under the Comprehensive Environmental Response, Compensation, and Liability Act. Therefore, APG has entered into an Interagency Agreement with the U.S. Environmental Protection Agency to address the listed areas.

The Kings Creek portion of the Edgewood Area (Figure 1) requires a Source Definition Study because the potential exists for release of volatile organic compounds into the aquifer system. A report prepared by the EAI Corporation included a list of 29 potentially contaminated buildings in the Edgewood Area (1989). The buildings have been abandoned and operations have ceased, but processing equipment, incinerators, sumps, drains, ventilation systems, and underground storage tanks remain. These appurtenances may contain liquid, solid, or vapor contaminants of unknown nature. Sixteen of the buildings contain known contaminants, nine buildings contain unknown contaminants, and four of the buildings are potentially clean. The EAI report recommended that a sampling and monitoring program be established to verify contamination levels in and around each building. Most of the effort thus far has been in the western Canal Creek Area. 


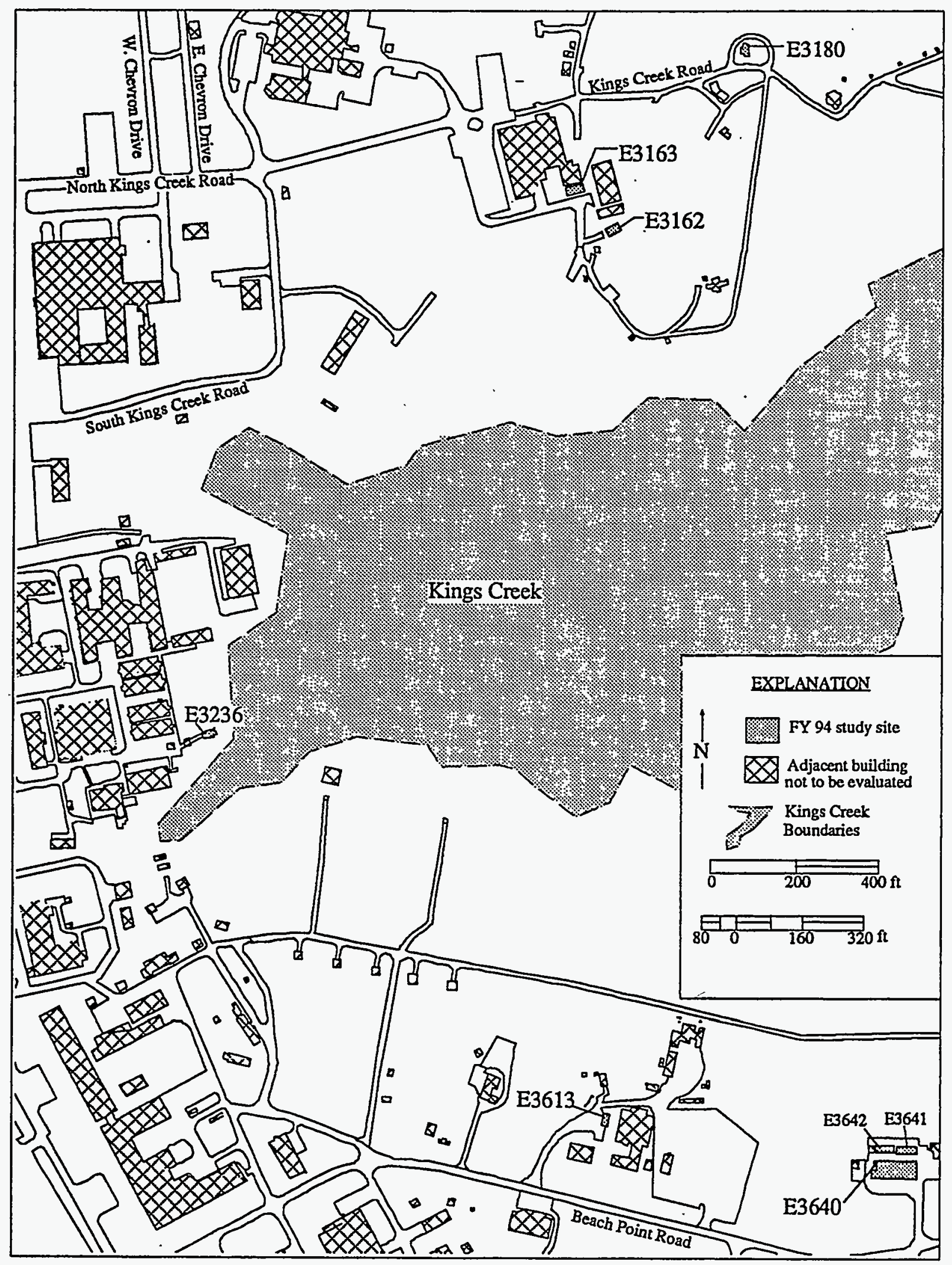

FIGURE 1 General Site Map of the Kings Creek Area, Aberdeen Proving Ground, Md. 
Six of the potentially contaminated buildings, including Building E3180, are in the drainage basin of Kings Creek. Aberdeen Proving Ground is proceeding with a program to decommission the buildings, which will eliminate the actual or potential release of contaminants into the environment. Argonne National Laboratory (ANL) has been assigned the task of developing a plan and scope of work for the proposed decommissioning. Argonne has determined that the first step in this decommissioning process, where it is technically feasible, should be a noninvasive geophysical survey around building exteriors.

\subsection{History of Building E3180}

Building E3180 is located at the eastern end of Kings Creek Road (Figure 1). According to the building records examined by EAI Corporation (1989), the building was constructed in 1944 and served as a Japanese pillbox model. The building was not used between 1957 and 1965. From 1965 to the early 1970s, it was operated as a flame and incendiaries laboratory, and from the early 1970s to 1988, it was used as a machine (metal) shop. Activities at the building ceased after 1988.

The building is constructed on a concrete floor measuring $14 \mathrm{ft} \times 32 \mathrm{ft}$, and two additions have been built, measuring $3 \mathrm{ft} \times 7 \mathrm{ft}$ and $4 \mathrm{ft} \times 7 \mathrm{ft}$. The walls are composed of 8 -in. concrete blocks, and the roof is made of concrete and asphalt. No drainage systems are apparent, and an open (squirrel-cage) exhaust system is the only ventilation. Appurtenances associated with the building are limited to a metal duct on the north face, and a sidewalk to the south (see Figure 2).

Hazardous materials used at the building during its history include the following:

1965-Early 1970s

Plasticized white phosphorus

White phosphorus

Eutectic white phosphorus

Triethyl aluminum

Magnesium

Napalm

Nonagent thickener

Red phosphorus

Thermite

Early 1970s-1988

Petroleum, oil, lubricants

Other (unknown) solvents. 


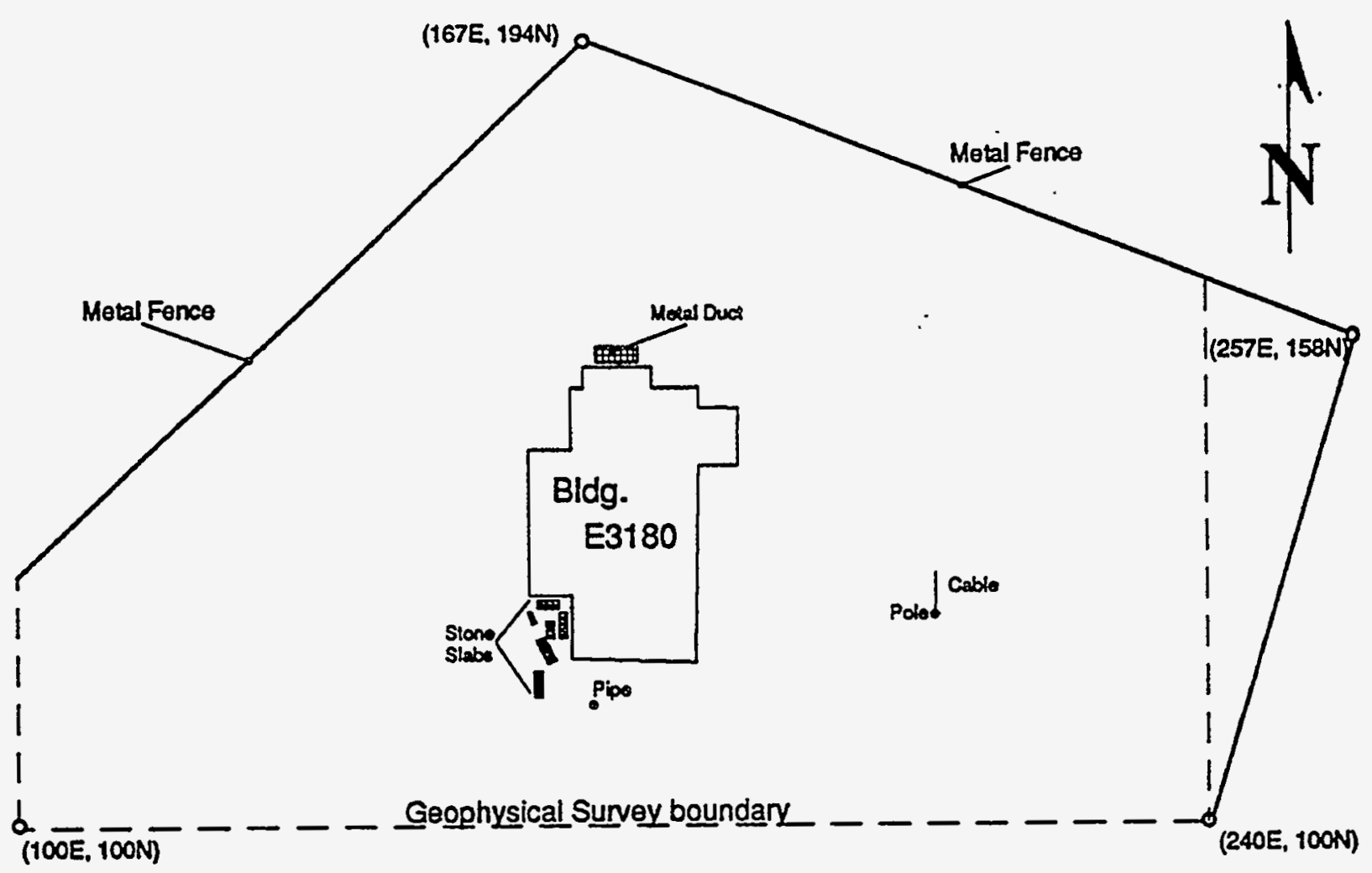

FIGURE 2 Detailed Location Map of Building E3180

As a result of personal interviews conducted by the EAI Corporation (1989), it was concluded that all incendiary material was consumed during laboratory operations. Since no written documentation exists, the building was categorized as having potentially unknown contamination.

\subsection{Site Reconnaissance}

A geophysics program was initiated in conjunction with decommissioning Building E3180 that was based upon similar programs conducted by ANL personnel at APG since 1991 (McGinnis and Miller 1991; L.D. McGinnis et al. 1992a,b, 1994; M.G. McGinnis et al. 1992a,b; Miller et al. 1992a,b; Thompson et al. 1992a,b, 1994; Benson et al. 1995; Daudt et al. 1995). The initial evaluation was enhanced by a November 1991 site visit and by inspection of aerial photos available to Argonne personnel. The building is located on level terrain adjacent to a marsh that borders the western margin of Kings Creek. The site is accessible from the west and south sides and is grass-covered around the perimeter of the building. A metal chain-link fence borders the site on the northwest, north, and east sides (Figure 2).

In addition to surface conditions at the site, subsurface characteristics were considered in planning the geophysical survey. Surficial sediments consist of estuarine sands, silts, and clays that are nonmagnetic and have electrical properties that vary both horizontally and vertically due to natural conditions or excavation and building effects. Such multiple sources as iron-rich 
magnetized objects, nonmagnetic objects, and subsurface channels containing contaminants may be present in the subsurface.

\subsection{Geology and Physiographic Setting}

The Kings Creek area is contained in topographically low and flat terrain of the Coastal Plain physiographic province, where alluvial and estuarine sands, silts, and clays underlay the region. A thin veneer of sediments of the Talbot Formation of Pleistocene age overlies unconsolidated sediments of the Potomac Group of Cretaceous age (Oliveros and Gernhardt 1989).

Lithologies at the site were determined from the four wells (sites \#8, \#104, \#117, and \#136) located in the vicinity of Building E3180. Of these, only well \#8 had lithologic samples for the upper $30-40 \mathrm{ft}$ of sediment. The relatively shallow depth range is critical to the geophysical interpretation because the penetration depth for the geophysical techniques used at Building E3180 does not generally exceed $40 \mathrm{ft}$. Borehole \#8 was drilled approximately $1,100 \mathrm{ft}$ west of Building E3180. The descriptive log for borehole \#8, given in Table 1, was part of a hydrogeologic study of the Canal Creek Area performed by the U.S. Geological Survey (Oliveros and Gernhardt 1989).

Facies represented include a 3-ft layer of silty soil, followed by a clay zone with thin silt and sand lenses. A thick layer of sand starts at $54 \mathrm{ft}$ in depth. The upper $30 \mathrm{ft}$ of the sedimentary section consists primarily of clay units. Inspection of the ground surface around Building E3180 indicates that some excavation and backfilling must have occurred during construction; thus, the upper $5 \mathrm{ft}$ of material is most likely construction fill.

\subsection{Surveys}

Geophysical data were acquired during two days of field operations during late June and early July 1994. On-site personal computers, interactive software, and field equipment designed specifically for APG building studies were used to expedite data acquisition and processing. After an initial scan with a magnetic gradiometer, surveys were conducted to measure total-field magnetics, electrical conductivity, induced EMF, and ground-penetrating-radar (GPR) profiles.

\subsection{Survey Grid and Locations of Observations}

Prior to geophysical data acquisition, the limits of a polygon-shaped survey area surrounding the building were established by marking the corners with wooden stakes (see Figure 2). A metal chain-link fence forms the northwestern and northern borders of the survey area. The $y$-direction was designated as parallel to the length of the building; the $\mathrm{x}$-direction was perpendicular to the length of Building E3180, along the longest side of the survey area. The longest dimensions of the polygon-shaped area were $140 \mathrm{ft}$ along the $\mathrm{x}$-direction and $94 \mathrm{ft}$ along the $y$-direction.

Throughout this report, grid coordinates of specific locations shown in Figure 2 and in later figures are specified as $(\mathrm{x}, \mathrm{y})$, where $\mathrm{x}$ and $\mathrm{y}$ refer to approximately easterly and northerly 
TABLE 1 Lithologic Log of Well at Site No. 8

Description ${ }^{\mathrm{a}} \quad$ Depth $(\mathrm{ft}) \quad$ Thickness (ft)

Silty soil

3.0

3.0

Clay, red, yellow and gray mottled, plastic, dense

19.0

16.0

Clay, red, plastic, dense; with irregular white, silty zones

40.1

21.1

Clay, gray, friable, micaceous; mixed with red clay as above

42.7

2.6

Clay, red, plastic, dense; with irregular, white silty zones and an olive green, mineralized front at the contacts

48.4

5.7

Sand, silty, light gray, poorly sorted, micaceous

52.5

4.1

Clay, red, plastic, dense; with irregular white zones and green mineralization as above

54.0

1.5

Sand, gray, well-sorted (fU-mL); with alternating lenses of dark gray, plastic clay

Sand, gray to tan, well-sorted $(\mathrm{mU})$

64.0

10.0

Sand, silty, gray, lignitic

66.7

2.7

67.1

0.4

Sand, gray, well-sorted $(\mathrm{mL})$

69.0

1.9

Sand, silty, wet, brown; with red-black concretions

71.4

2.4

Sand, clayey, white, (fU); with yellow and lavender laminae

72.0

0.6

Sand, silty, multicolored, micaceous

74.7

2.7

Sand, brown, clean, well-sorted $(\mathrm{mU})$; with multicolored laminae

89.0

14.3 and gravel (1-4 in.)

No sample

168.4

79.4

Sand, gray $(\mathrm{mL})$ clean

168.7

0.3

Clay, gray and tan mottled, plastic, dense, micaceous

170.8

2.0

No sample

188.1

17.4

Clay, sandy, dark gray, lignitic

190.1

2.0

No sample

199.1

9.0

Clay, gray, micaceous, lignitic; with some floating gravel up to

199.8

0.7 0.5 in.

a Codes enclosed in brackets at selected horizons refer to color designations as specified in the Munsell Soil Color Charts (1975).

Source: Oliveros and Gernhardt (1989). 
directions, respectively. Relative coordinate values are in feet. Grid coordinate values of (100, 100) were assigned to the southwest corner of the survey area. The geophysical profiles that are presented in this report were traversed in both $\mathrm{x}$ and $\mathrm{y}$ directions, generally with a profile spacing of $5 \mathrm{ft}$. 


\section{Instrumentation}

\subsection{Magnetic Gradiometer and Cable Locator}

The Schonstedt MAC-51B magnetic gradiometer and cable locator is a dual-mode instrument designed for detecting shallow-buried iron and steel objects and tracing underground cables and pipes. The system consists of a transmitter and a dual-function receiver designed to detect anomalous magnetic gradients. The MAC-51B is an audio device used only for rapid detection of magnetic materials for further analysis with complementary instrumentation.

Maps or models are not constructed from observations made with this instrument because it is not a calibrated system and it does not have digital data recording. Anomalies are identified by changes in sound amplitude and frequency and are marked on the ground surface prior to the initiation of other surveys. If anomalies detected with the MAC-51B cannot be verified with the magnetometer (see Section 2.2), the anomaly is assumed to be insignificant.

Application of the MAC-51B in its receiver mode is the first geophysical operation following establishment of survey limits. A qualitative description of the site with 100 percent ground coverage is achieved by using the gradiometer, whereas the results obtained with the other techniques, although more quantitative, are spatially limited to single-point survey-grid observations or to continuous readings along spaced profiles.

\subsection{Total-Field Magnetics Meter G-822L}

Magnetometer surveys were conducted to identify such ferromagnetic objects as tanks, drums, drain pipes, water lines, and small ferrous objects. An EG\&G Geometrics G-822L cesium-vapor magnetometer was used to measure the total magnetic field around Building E3180. The G-822L was operated in a continuously recording mode and acquired magnetic measurements at intervals of approximately $0.3 \mathrm{ft}$.

Because of the dipolar field, a magnetic anomaly due to a source having a simple physical shape exhibits a characteristic signature consisting of a positive magnetic peak and at least one negative magnetic trough. If a symmetrically shaped body of iron-rich waste is buried in the northern hemisphere and becomes magnetized in the earth's field, a large positive anomaly with a weak negative offset to the north will occur. The horizontal distance between the paired peak and trough is proportional to the depth of burial, the size, and the shape of the source, whereas the amplitude of the anomaly is inversely proportional to the depth of burial. Metallic debris at, or just below, the ground surface produces strong, closely spaced, magnetic peaks and troughs, separated by high-gradient areas.

When using the G-822L magnetometer, the sign of magnetic anomalies must be viewed with extreme caution, because in a region of high gradients, the magnetometer becomes untuned and provides zero readings. Contouring software for the G-822L has been designed to bridge the zero gap with mean values taken from the last readable data along the profile. Thus, because of the bipolarity of magnetic anomalies and the variability of gradients, it is possible for an isolated anomaly or a lineament to change from a positive to a negative feature along the trend. For the 
purpose of this study, the polarity of the anomaly is unimportant. The absolute strength of the magnetic anomaly and whether the anomaly appears as a "point" source or a linear feature are more important to the geophysical interpretation.

\subsection{Conductivity Meter EM-31}

Mean conductivities were obtained with the Geonics EM-31, an electromagnetic (EM) induction instrument that measures mean terrain conductivity to depths of approximately $20 \mathrm{ft}$. The induction coil of the EM-31 transmits an EM field into the ground, and a receiver measures the secondary magnetic field caused by the low-intensity eddy currents induced in the subsurface. The field strength of the secondary magnetic currents are almost linearly proportional to the electrical conductivity of the surrounding sediment.

Data were collected at 0.5-s intervals with the EM-31 and were stored on the OMNI 720 data logger, which can log quad-phase electrical conductivity data and in-phase inductive data for metals simultaneously, as well as store survey geometry. Data for this survey were recorded in quad-phase only. Internal software permits downloading directly into an on-site computer. Conductivity contouring is incorporated into the field acquisition procedure so that daily map outputs can be available for observation and interpretation. EM methods have been used extensively in the Edgewood Area at Beach Point, J-Field, and various buildings surveyed by ANL staff.

\subsection{Time-Domain Millivolt Meter EM-61}

Field data were obtained in millivolts with a Geonics EM-61, a portable, time-domain, electrical induction instrument that transmits an electrical pulse into the ground and measures secondary EMFs caused by metallic objects beneath the instrument. As a consequence of its coil arrangement, the EM-61 is relatively insensitive to surface interference but more sensitive to deeply buried metallic targets. Data are recorded on three channels, including the response from an upper coil, a lower coil, and a coil difference.

The lower coil, because of its spatial positioning, responds to signal from all depths within the instrument range. According to the manufacturer's claims, the lower coil can detect an anomaly of $2 \mathrm{mV}$ caused by a 55-gal metal drum buried at a depth of about $9 \mathrm{ft}$. Inspection of the data sets acquired at Building E3180 and other APG sites surveyed by ANL personnel indicate that the measurements obtained from the lower coil are sufficient to identify buried metallic sources within the gridded area.

Data were collected at a rate of three readings per second and were stored on the OMNI 720 data logger. Internal software permits downloading directly into an on-site computer. Contouring of data in millivolts is incorporated into the field acquisition procedure so that daily map outputs can be available for observation and interpretation. 


\subsection{Ground-Penetrating-Radar System}

Ground-penetrating-radar surveying and data processing were accomplished using a Geophysical Survey Systems, Inc., SIR-3 radar system and Radan III software (Galinovsky and Levin 1990). A 300-MHz monostatic-transceiver-antenna system was tethered to the SIR-3 with a 100-ft cable. Data were recorded on a digital audio tape to permit playback. The SIR-3 control unit/graphic recorder was located in the transport vehicle. A computer was located in a field office, so that the radar operator could download, check data quality, and do preliminary processing after a day's run.

Wave-velocity characteristics of near-surface materials were derived from known positions of buried objects. Internal calibration was run at least twice each day to ensure that the graphic record of the range setting was consistent. Studies conducted during the 1991, 1992, and 1993 field seasons indicate GPR travel times of 7-9 ns/ft for near-surface sediment (Geophysical Survey Systems, Inc. 1987). However, conditions vary with the heterogeneity of the subsurface.

Ground-penetrating radar is the best method available to determine depth and geometry of objects buried near the surface. The weakness of the method is its limited depth of exploration due to wave-propagating constraints imposed by the electrical properties of soils. The recorded range of GPR data at Building E3180 was $70 \mathrm{ns,} \mathrm{which} \mathrm{corresponds} \mathrm{to} \mathrm{an} \mathrm{approximate} \mathrm{depth} \mathrm{range} \mathrm{of} \mathrm{0-}$ $10 \mathrm{ft}$ below the ground surface. The actual sensitivity of the GPR recording system is probably less than half of the $0-10 \mathrm{ft}$ depth range. Depths are calculated from known travel times through earth materials found at APG. 


\section{Geophysical Measurements and Surveys}

Color-contour maps of the total magnetic field, terrain conductivity, and time-domain EMF data presented in this report were constructed from the survey data by using software developed at ANL (Thompson 1994). The data set comprises 8,770 magnetics measurements; 2,360 conductivity measurements; and 2,333 EMF measurements. Profile plots of selected GPR transects are also presented and represent a data set comprising 3,642 linear feet of profiling.

On each color-contour plot, the following coloring convention is maintained: Building E3180 is depicted as a solid white polygon and cement structures or pads as patterned rectangles. Where possible, a descriptive name was also overlain onto the color diagram.

Gridding of data was accomplished with a minimum curvature technique using one of two computer programs: MINC, produced by the U.S. Geological Survey (Cordell et al. 1992); and SURFER, produced by Golden Software, Inc. (1991). Documentation supplied with the MINC program suggests that grid intervals from one-half to one-fifth of the profile spacing will yield adequate gridding results for data acquired along profiles. A grid interval of $1.0 \mathrm{ft}$ was used for each set of grid data and represents a grid interval of one-fifth of the profile spacing $(5 \mathrm{ft})$.

\subsection{Total-Field Magnetics}

The magnetic field measured around Building E3180 is shown in Figure 3. Also depicted are the magnetometer profiles, which were run in both $\mathrm{x}$ - and $\mathrm{y}$-directions. The magnetic field around Building E3180 is dominated by anomalies caused by the steel fence and the building. Examination of Figure 3 shows that magnetic data within $7 \mathrm{ft}$ of the steel fence cannot be used.

Several other magnetic anomalies are also attributed to features visible at the surface. A 10-ft diameter magnetic high located immediately north of Building E3180 is probably caused by the adjacent metal duct (see Figure 2). The magnetic high/low pair, located at grid coordinates $(210,134)$, is due to the guy-wire and anchor stake that support the utility pole to the east of the building.

Low magnetic anomalies located adjacent to the building are generally attributed to magnetic material associated with the building structure. The anomaly on the eastern edge of the building, which extends outward nearly $10 \mathrm{ft}$, may in part be attributed to buried metallic material.

An 8-ft wide magnetic low extends from the southwest corner of Building E3180 and exits the survey area to the south. The northern half of this anomaly is spatially located over a cluster of stone/cement slabs that presumably once formed a sidewalk. The southern half of the anomaly may be caused in part by a continuation of this walkway. However, the anomaly is also adjacent to a vertical pipe that is located at grid coordinates $(165,115)$ (shown in Figure 2); the anomaly may be caused by a buried metallic object associated with the pipe. 


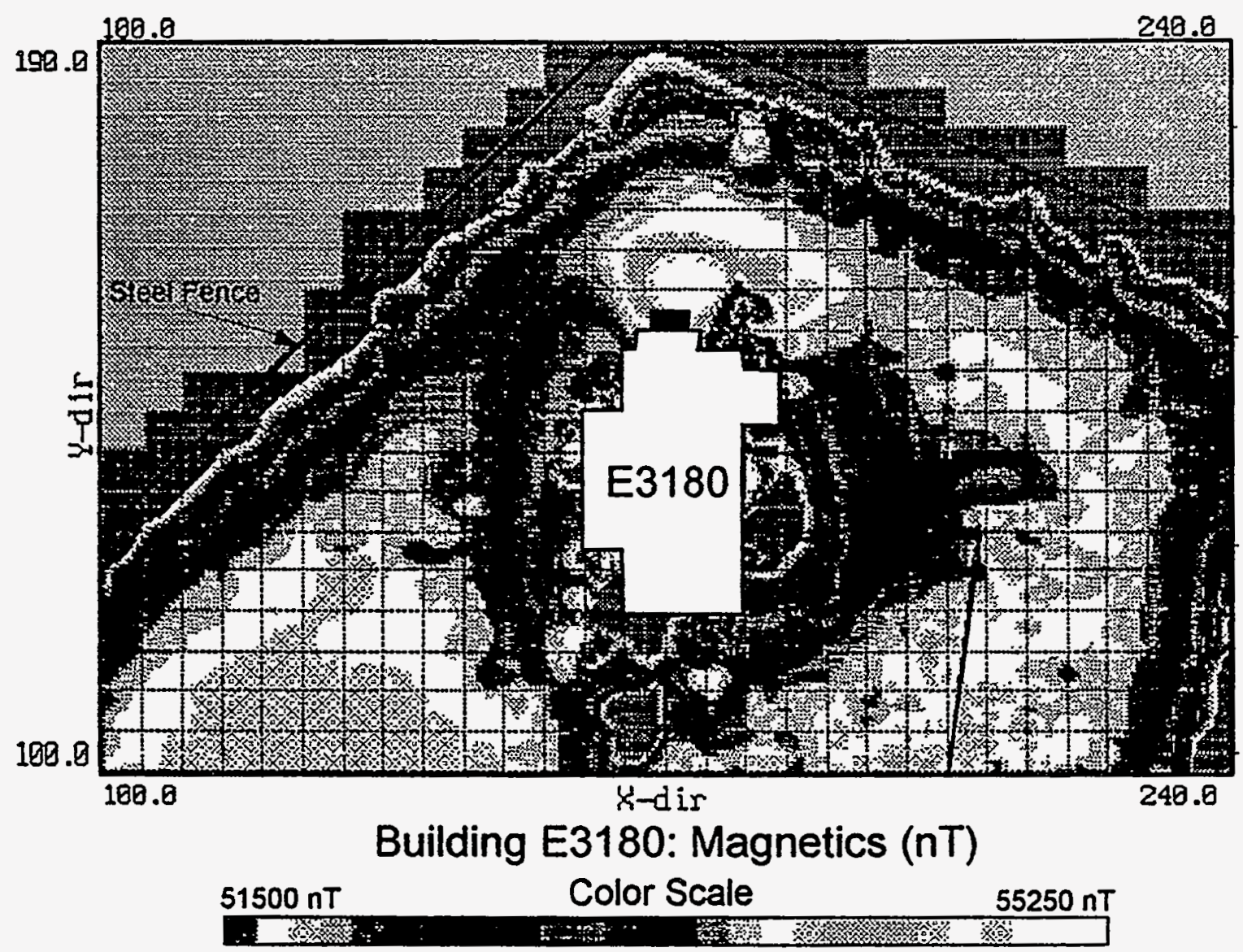

FIGURE 3 Total Magnetic Field Anomaly Map

An isolated magnetic high with a diameter of $4 \mathrm{ft}$ is located $5 \mathrm{ft}$ east of the walkway and of the pipe at grid coordinates $(170,112)$. This anomaly, which has no apparent surface expression, coincides with a relatively large EMF anomaly. The source of the anomaly is unknown.

Other isolated magnetic anomalies are not associated with any readily observable surface expressions. Sources for anomalies located at grid coordinates $(150,110) ;(140,130) ;(145,135)$; $(205,150)$; and $(180,180)$ are most probably buried metallic debris.

\subsection{Terrain Conductivity Measurements}

Figure 4 shows the mean electrical conductivity for the upper $20 \mathrm{ft}$ of sediment around Building E3180. Figure 4A shows a color map derived from profiles conducted parallel to the $\mathrm{x}$-axis, while Figure $4 \mathrm{~B}$ shows a color map derived from profiles conducted parallel to the $\mathrm{y}$-axis. The data were contoured using a contour interval of $2 \mathrm{mS} / \mathrm{m}$. As with the magnetic anomaly map, the effects of the steel fence dominate much of the figure, and conductivity data acquired within $15 \mathrm{ft}$ of the fence line are not usable. 

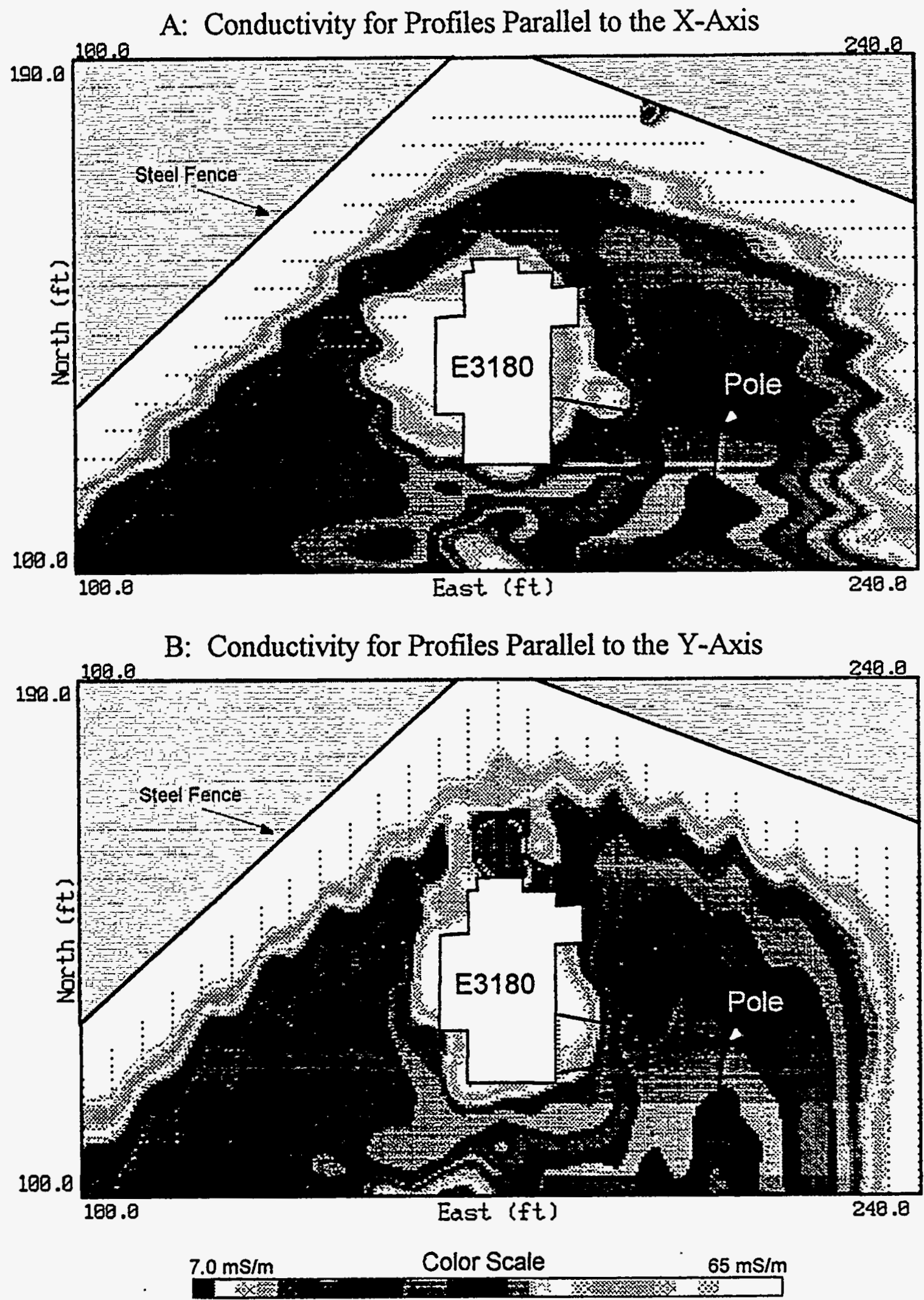

FIGURE 4 Terrain Conductivity Anomaly Map 
A conductivity low centered at grid coordinates $(170,162)$ is probably due to the metal duct attached to the building's northern wall. The east-west-oriented profile data in Figure 4A along $\mathrm{y}=160 \mathrm{ft}$ do not show such an anomaly; only the perpendicular profile data in Figure 4B along $\mathrm{x}=170 \mathrm{ft}$ show the low anomaly. The apparent discrepancy of conductivity values at the intersection of the two traverses is due to the orientation of the Geonics EM-31 boom, which is always carried parallel to the direction of the profile during the survey. The transmitter coil of the Geonics EM-31 boom came in proximity to the metal duct during the north-south traverse in the vicinity of the two perpendicular profiles.

The complex pattern of conductivity lows southwest of the building and adjacent to the southern border of the survey area might be caused in part by gravels used as grade material for the adjacent access road to the building. However, the strongest low, located at grid coordinates $(175,100)$, overlaps the strong magnetic low southwest of the building described previously (Section 3.1; see Figure 3). The cause of this low conductivity anomaly is not known. A trend of positive conductivity anomalies extending southwest from the building to grid coordinates $(150,105)$ may be related to the same source.

High conductivities immediately adjacent to the building are primarily attributed to metallic material associated with the building structure. Like the magnetic data, however, the anomalies may be caused partly by buried metallic sources, particularly on the east side of the building.

\subsection{Induced-EMF Measurements}

A color-contour map constructed from the Geonics EM-61 lower coil data, which represents all signal to an approximate depth of $9 \mathrm{ft}$, is shown in Figure 5. As with other potentialfield data, strong positive EMF anomalies attributed to the steel fence dominate the edges of the survey area. Similarly, metallic construction material associated with Building E3180 also had a dominating effect on data collected close to the building. The guy-wire and anchor stake for the adjacent utility pole at grid coordinates $(210,130)$ probably caused the positive EMF anomaly at that location, just as it did for magnetic data.

The strong EMF anomaly associated with Building E3180 extends relatively far from the building, both from the south wall and from the southwest corner. In both locations, the anomaly extends more than $10 \mathrm{ft}$ from the building in proximity to the EMF anomaly at coordinates (162, 102) (discussed below). The anomaly at the southwest corner is adjacent to the vertical pipe located at grid coordinates $(165,115)$ (Figure 2) and is coincident with a strong magnetic low. The anomaly at the south wall is coincident with the isolated magnetic high located at grid coordinates $(170,112)$. The sources of the anomalies are unknown.

The low anomaly immediately north of the building is a gridding artifact. Steep gradients caused by the building to the south and by the fence to the north force the minimum curvature algorithm to calculate a false anomaly. Neither east-west profiles along $y=160 \mathrm{ft}$ nor the profiles along $\mathrm{y}=180 \mathrm{ft}$ exhibit a strong conductivity low. 


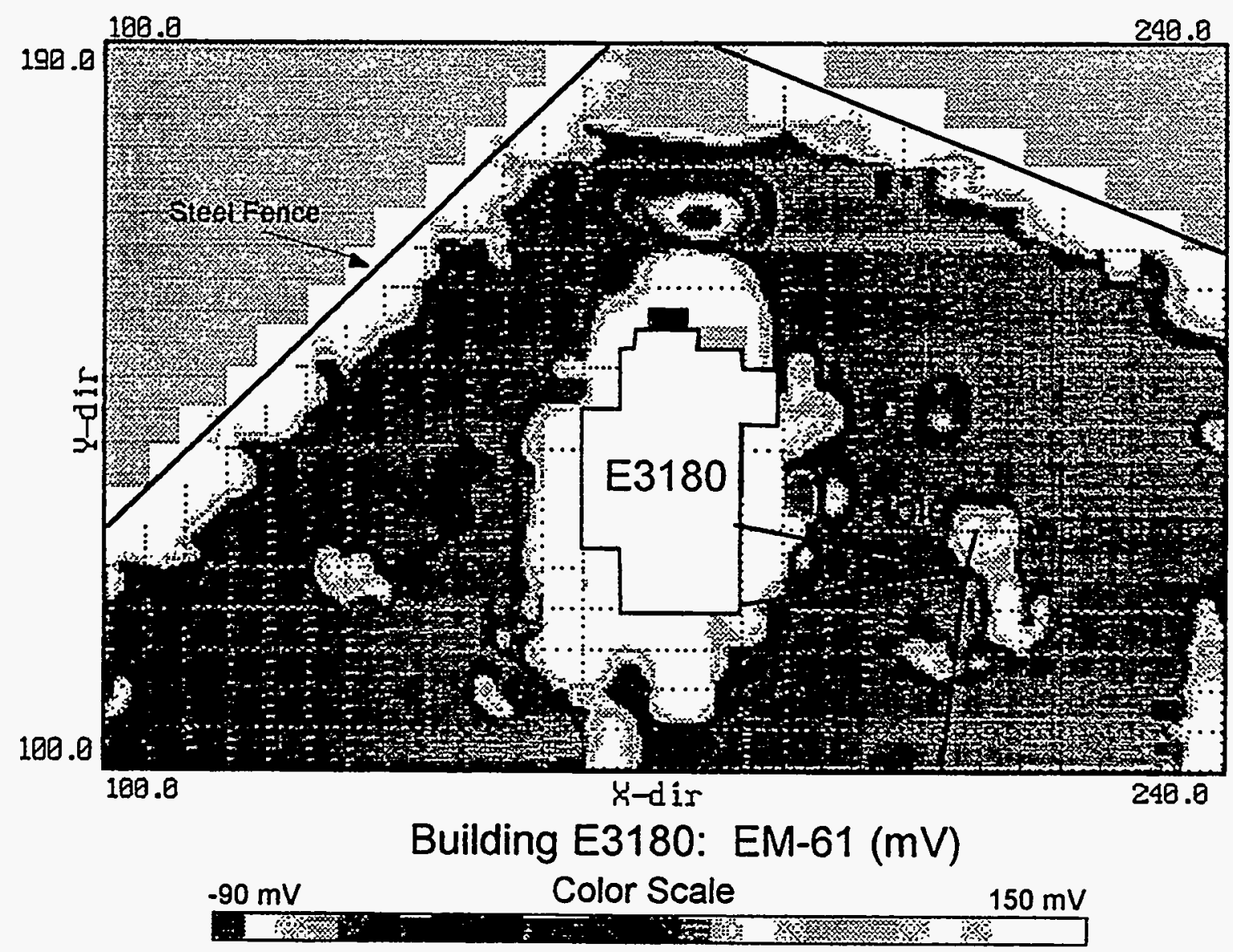

FIGURE 5 EMF Anomaly Map

Along the southern border of the survey area, south of Building E3180, a north-southoriented EMF positive anomaly was observed at grid coordinates $(162,102)$. The anomaly is coincident with a conductivity low and overlaps a magnetic low.

A relatively strong positive EMF anomaly was observed at grid coordinates $(130,125)$, coinciding with a weak magnetic anomaly. Isolated positive EMF anomalies were also observed at grid coordinates $(102,108) ;(150,110) ;(145,137) ;(140,132) ;(203,115) ;(213,120) ;$ and $(205,145)$. Many of these anomalies are coincident with magnetic anomalies. No surface expressions were observed, and these anomalies are interpreted to be due to buried metal debris.

\subsection{Ground-Penetrating-Radar Measurements}

Coordinates of GPR lines from the Building E3180 survey are shown in the Attachment. The lines are numbered in sequence, along with the beginning and ending positions relative to the grid survey. Prior to running the production lines for the survey, replicate runs were made over the same line to determine which of the three transceivers, the $80-, 300-$, or 500-MHz antenna, was best suited to study the terrain surrounding the site. The transceiver providing the best penetration 
and resolution of buried objects was the $300-\mathrm{MHz}$ unit. Different range settings were also tested over the same transect to determine the optimum resolution and depth of penetration. A range setting of $70 \mathrm{~ns}$ at a scan rate of 32 scans per second was used for the entire survey.

Without verification by another technique or by passing the antenna over an object of known depth, characteristics of radar anomalies may only be inferred. However, where anomalies are also seen with magnetic or resistivity profiling, a diagnostic interpretation of the radar anomaly is possible. Good penetration was observed over most of the site, with resolution down to about $8 \mathrm{ft}$ below the ground surface.

Figure 6 shows a summary of GPR anomalies observed for the Building E3180 geophysical survey area. A zone of anomalous GPR reflections was observed within a distance of about $35 \mathrm{ft}$ around much of the perimeter of the building. Generally, at each location where a potential-field anomaly was observed, a GPR anomaly was also observed. However, the converse was not always the case, particularly within the zone described above, suggesting that the sources of many of the GPR reflections are predominantly nonmetallic in composition. The zone of GPR reflections around the building probably represents an area of disturbed sediments or an area covered with sedimentary fill material.

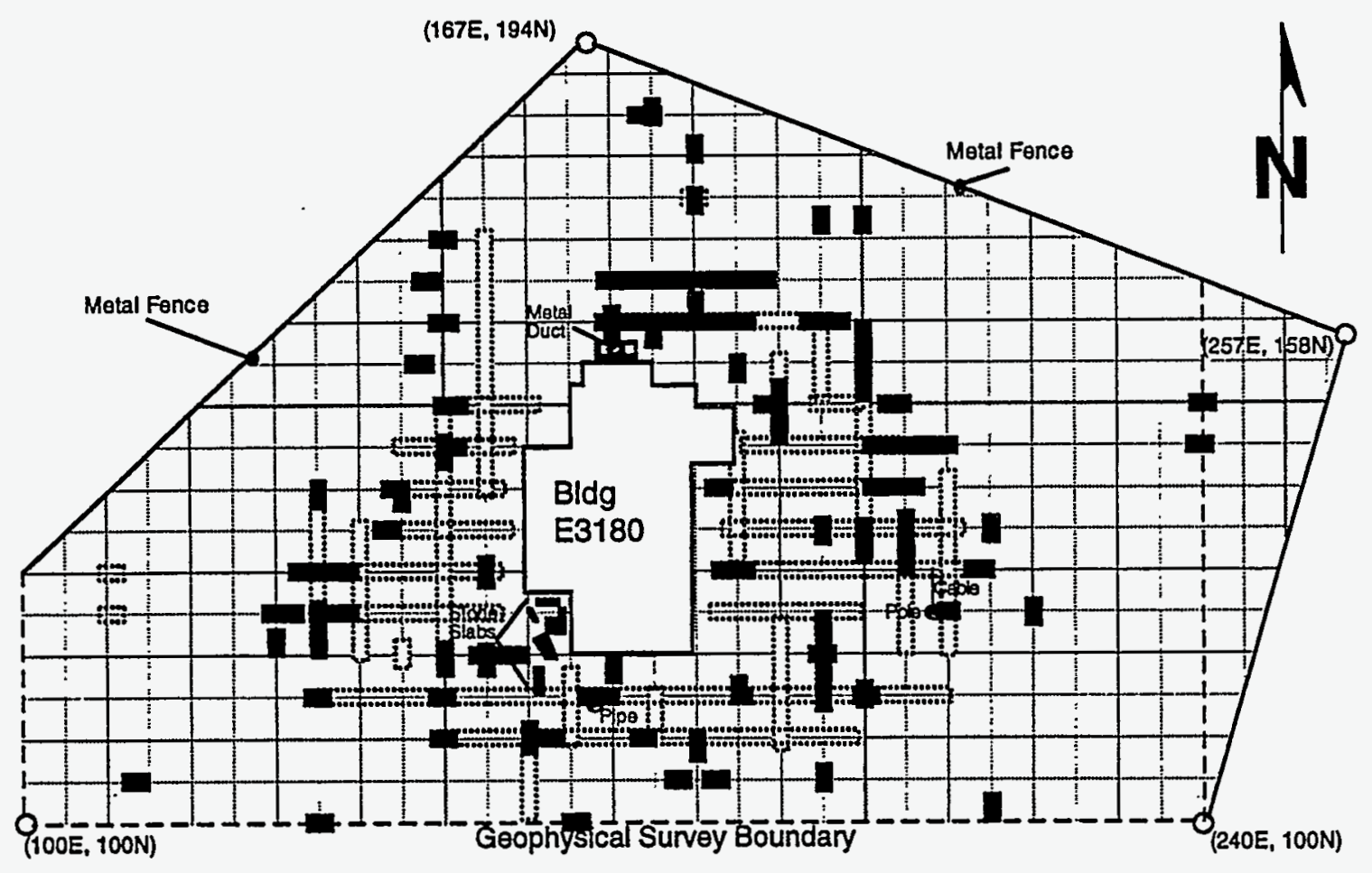

Locations of relatively strong GPR anomalies :-:: Locations of relatively weak GPR anomalies

FIGURE 6 Locations of Anomalous GPR Reflectors for Building E3180 
Two east-west profiles on the west side of building, corresponding to $y=125 \mathrm{ft}$ and $y=130 \mathrm{ft}$, are shown in Figures 7A and 7B, respectively. Both profiles show a series of strong GPR reflections within the zone described above, located between $\mathrm{x}=140 \mathrm{ft}$ and the building (at $\mathrm{x}=160 \mathrm{ft}$ ). They are typical of adjacent GPR profiles on the west side. The strongest reflectors appear to be within a depth range of 1.0-2.5 $\mathrm{ft}$. Both profiles also show an apparent dipping reflection at the leading edge of the anomaly. The reflection is observed at about $\mathrm{x}=138 \mathrm{ft}$, at a depth of about $6 \mathrm{ft}$.

A few GPR reflections on the west side of the building do coincide with potential-field anomalies. A relatively isolated, but nevertheless strong, GPR reflection is also observed further west in the GPR profile for $y=125 \mathrm{ft}$ (Figure 7A). The reflection, centered at $\mathrm{x}=130 \mathrm{ft}$, has a depth of about $1 \mathrm{ft}$ and is coincident with a strong EMF anomaly (Figure 5) and a relatively high magnetic anomaly (Figure 3). The source of the anomalies is probably a buried metallic object at that location. A GPR reflection (Figure 6) corresponds to the magnetic anomaly located at grid coordinates $(150,110)$ and also probably indicates a buried metallic object. Magnetic anomalies are also observed within the zone of GPR reflections near the west side of the building at grid coordinates $(140,130)$ and $(145,135)$ (Figure 6).

A subtle trend of GPR reflections was observed that did not have corresponding potentialfield signatures. The trend, extending along $\mathrm{x}=150 \mathrm{ft}$ to the northern limit of the survey area, may indicate the location of a linear, nonmetallic object below the surface (for example, a clay tile). Two GPR reflections along the trend can be seen in the left part of the profiles shown in Figures $8 \mathrm{~A}$ and $8 \mathrm{~B}$, corresponding to $\mathrm{y}=160$ and $\mathrm{y}=165 \mathrm{ft}$, respectively. The GPR reflections are subtle, and excavation will be necessary to confirm either the presence or absence of a buried object.

Immediately north of the building, the zone of strong GPR reflections is pronounced, particularly in the vicinity of a metal duct centered at grid coordinates $(170,155)$. Anomalies are observed in all of the potential-field data sets at this location, and they are primarily attributed to the metal duct. The GPR profiles shown in Figures $8 \mathrm{~A}$ and $8 \mathrm{~B}$ continue east immediately north of the metal duct to the east side of the survey area. Both profiles show reflections dipping to the west in the vicinity of the metal duct $(\mathrm{x}=170 \mathrm{ft})$ and dipping back to the east further east along the profiles. The dipping reflections have a depth of about 4-5 ft. Unlike the anomalies delineated by the potential-field data, the GPR anomalies continue nearly $25 \mathrm{ft}$ east of the metal duct to about $\mathrm{x}=200 \mathrm{ft}$. While the GPR anomalies may be caused partly by buried objects, they are probably more indicative of the lateral extent of ground disturbance near the building.

Two east-west profiles on the east side of building are shown in Figures 9A and 9B, corresponding to $y=130$ and $y=140 \mathrm{ft}$, respectively. As with profiles on the west side of the building, the profiles at the east side show a series of strong GPR reflections within the anomalous zone close to the building, located between the building $(x=180 \mathrm{ft})$ and $x=220 \mathrm{ft}$. The strongest reflectors appear to be within about $2 \mathrm{ft}$ of the surface. Adjacent and north-south profiles are similar in character within the anomalous zone. 
A. GPR PROFILE E $3180-54$ (125N)

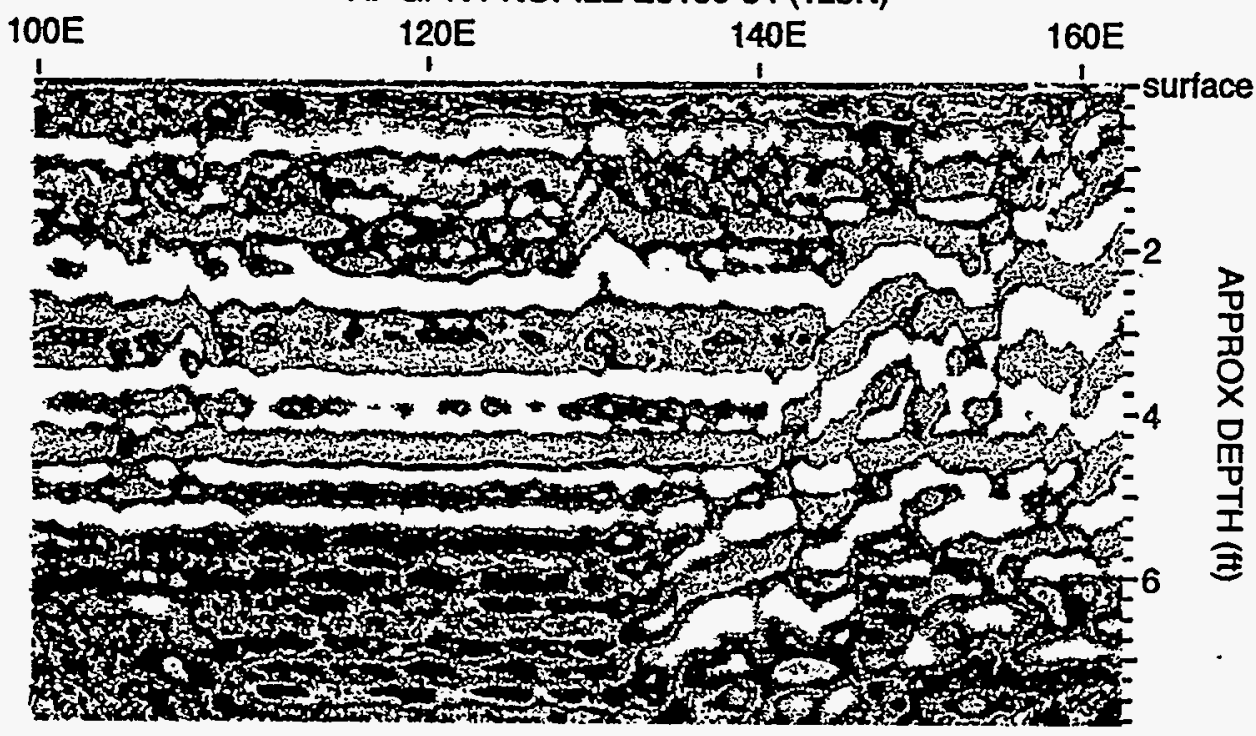

B. GPR PROFILE E3180-55 (130N)

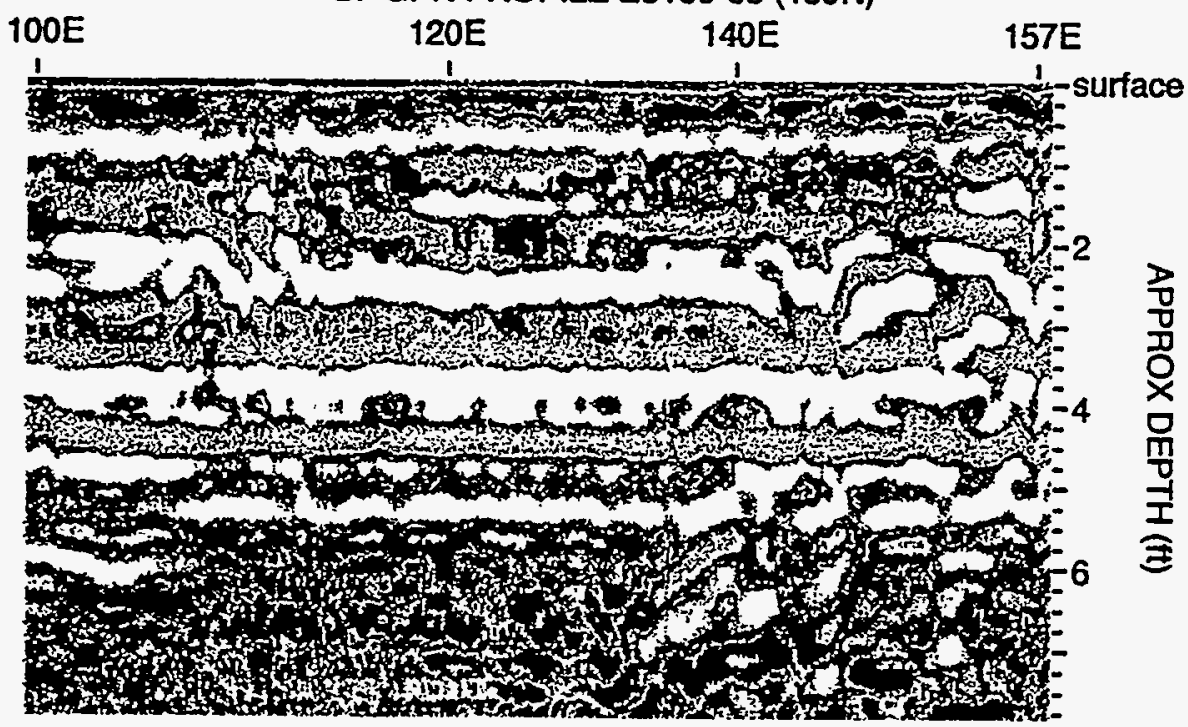

FIGURE 7 Two Adjacent West-to-East GPR Profiles on West Side of Building E3180 

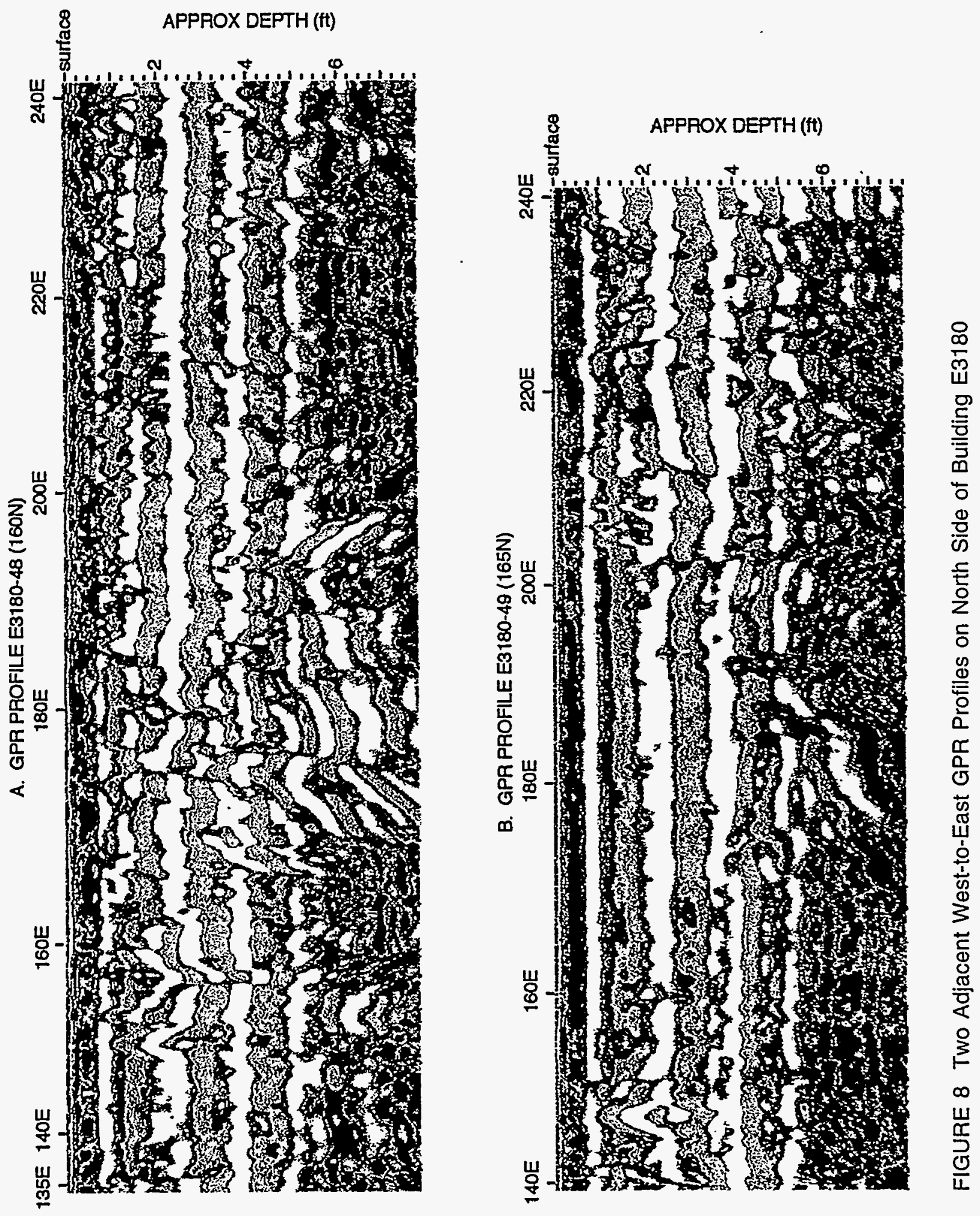

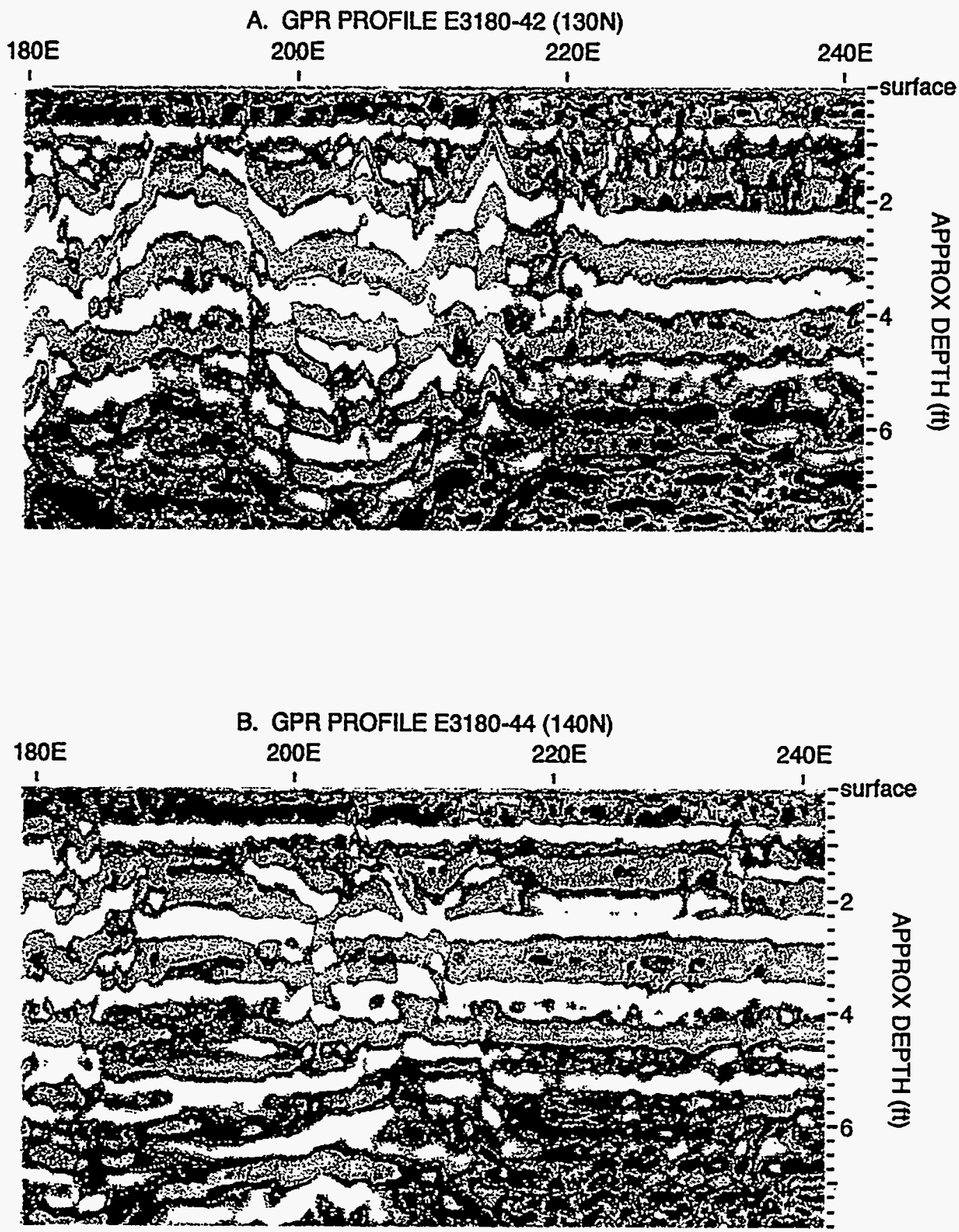

FIGURE 9 Two Nearly Adjacent West-to-East GPR Profiles on East Side of Building E3180 
The strong reflection at about $\mathrm{x}=215 \mathrm{ft}$ in Figure 9 A may be caused by the steel cable supporting the utility pole at grid coordinates $(210,125)$. However, the cable intersects the ground at grid coordinates $(210,130)$, whereas the GPR reflection is $5 \mathrm{ft}$ further east. Magnetic and EMF data also show anomalies at the location of the GPR anomaly, at about grid coordinates $(215,130)$, suggesting a buried metallic source.

GPR reflections within about $10 \mathrm{ft}$ of the building in Figures 9A and 9B $(x=180-190 \mathrm{ft})$ coincide with a strong negative magnetic anomaly. The GPR reflections are somewhat distorted by the building; they do not suggest the presence of any large, metallic objects below the surface near the building. The magnetic anomalies are probably caused by metallic material in the building.

GPR anomalies south and southwest of the building were generally similar to reflections observed within the $35-\mathrm{ft}$ anomalous zone on the other sides of the building. Anomalous reflections were generally observed at locations of the strong potential-field anomalies that were described above (Sections 3.1-3.3). However, the GPR anomalies at these locations (south of the building and between $\mathrm{x}=150$ and $\mathrm{x}=180 \mathrm{ft}$ ) were similar to other GPR anomalies within $35 \mathrm{ft}$ of the building (Figure 6). The presence of buried objects can neither be confirmed nor rejected on the basis of the GPR data.

Isolated GPR reflections are observed throughout the survey area beyond the anomalous zone. Examples are the anomalies north of $y=170 \mathrm{ft}$ and east of about $x=230 \mathrm{ft}$. Generally, these anomalies occur without coinciding potential-field anomalies and do not have any discernible trend. They may be caused by bouncing of the antenna or other nongeologic effects. 


\section{Discussion}

With the exception of areas close to the fence or the building, especially near the southwest corner and south walls of the building, much of the Building E3180 site had a relatively quiet response to potential-field measurements (Figures 3-5). A few anomalies were observed that were not associated with any obvious surface features (the building, metal conduit, fence, steel wire supporting the utility pole, etc.). Most of the anomalies, which were generally of low amplitude and isolated, were probably caused by buried metallic debris. One of the larger isolated anomalies, located at grid coordinates $(130,125)$ had a radius of about $5 \mathrm{ft}$ in its EMF signature, a magnetic field contrast of less than $200 \mathrm{nT}$, and no apparent Geonics EM-31 response. The anomaly also produced a distinct GPR reflection (Figure 7A).

A stronger, perhaps important, group of anomalies was observed extending south from the southwest corner and the south wall of the building. The anomalies, located between $x=160 \mathrm{ft}$ and $x=175 \mathrm{ft}$ and between the building and the south edge of the survey area, were characterized by strong signatures in all three potential-field data sets. GPR data also showed anomalous reflections, although these reflections were not different from numerous others within about $35 \mathrm{ft}$ of the building. The anomalies are in close proximity to a vertical pipe located at grid coordinates $(165,115)$ (Figure 2) and appear to be associated with a former pathway to the entrance of the building. The southern edge of the survey area is adjacent to a roadway that may contain gravels that affect the potential-field measurements. However, the relatively strong anomalies may also indicate the presence of one or more buried metallic objects. Excavation is required to determine the presence of buried metallic objects in these areas.

Strong potential-field anomalies elsewhere along the edge of the building may also be caused in part by underground metallic objects, particularly on the east side of the building, where the anomalies extend several feet from the building. However, these anomalies may be caused entirely by metallic material in the building. As before, excavation is required to determine the presence of buried metallic objects in areas close to the building.

The zone of anomalous GPR data around the perimeter of the building is probably caused by nonmetallic sources, with the exception of the anomalies described above and a few isolated anomalies described in Section 3.4. Similarly, the linear trend observed in GPR reflections along $x$ $=150 \mathrm{ft}$ in the northern part of the survey area has no apparent metallic source associated with it. It may be caused by a buried clay tile or other nonmetallic linear object. 


\section{Conclusions}

Geophysical surveys around the Building E3180 site suggest that large buried metallic objects may occur between the building and the southern edge of the survey area or immediately adjacent to the building on the east, north, and west sides. Elsewhere around the site, buried metallic objects are probably of relatively limited size. Smaller anomalies (with a radius of $5 \mathrm{ft}$ or less) are observed at a few locations. GPR data reveal that the ground within about $35 \mathrm{ft}$ of the building has been disturbed. GPR data also show a north-trending anomaly northwest of the building that apparently is caused by a nonmetallic source. 


\section{References}

Benson, M.A., et al., 1995, unpublished information, Argonne National Laboratory, Argonne, Ill.

Cordell, L., J.D. Philips, and R.H. Godsen, 1992, Potential Field Geophysical Software: Version 2, U. S. Geological Survey Open-File Report 92-18.

Daudt, C.R., et al., 1995, unpublished information, Argonne National Laboratory, Argonne, Ill.

EAI Corporation, 1989, Historical Records Search and Site Survey of Edgewood Area Buildings, Final Report, prepared for U. S. Army Chemical Research, Development, and Engineering Center, Aberdeen Proving Ground, Md., under contract No. DAA15-87-D0021.

Galinovsky, L., and K. Levin, 1990, Radan III, Geophysical Survey Systems, Inc., North Salem, N.H.

Geophysical Survey Systems, Inc., 1987, Operations Manual for Subsurface Interface Radar (SIR System-3), North Salem, N.H.

Golden Software, Inc., 1991, SURFER Version 4, Golden, Colo.

McGinnis, L.D., and S.F. Miller, 1991, Interim Progress Report - Geophysics: Building E5032 Decommissioning, Aberdeen Proving Ground, ANL/ESD/TM-20, Argonne National Laboratory, Argonne, $\mathrm{Il}$.

McGinnis, L.D., et al., 1992a, Interim Progress Report - Geophysics: Building E5440 Decommissioning, Aberdeen Proving Ground, ANL/ESD/TM-42, Argonne National Laboratory, Argonne, Ill.

McGinnis, L.D., et al., 1992b, Geophysical Study of the Building 103 Dump, Aberdeen Proving Ground, ANL/ESD/TM-51, Argonne National Laboratory, Argonne, Ill.

McGinnis, L.D., et al., 1994, Environmental Geophysics: Buildings E5485, E5487, and E5489 Decommissioning - The "Ghost Town" Complex, Aberdeen Proving Ground, Maryland, ANL/ESD/TM-78, Argonne National Laboratory, Argonne, Ill.

McGinnis, M.G., et al., 1992a, Interim Progress Report - Geophysics: Building E5375 Decommissioning, Aberdeen Proving Ground, ANL/ESD/TM-37, Argonne National Laboratory, Argonne, Ill.

McGinnis, M.G., et al., 1992b, Interim Progress Report - Geophysics: Decommissioning of Buildings E5974 and E5978, Aberdeen Proving Ground, ANL/ESD/TM-47, Argonne National Laboratory, Argonne, Ill. 
McGinnis, M.G., et al., 1992b, Interim Progress Report - Geophysics: Decommissioning of Buildings E5974 and E5978, Aberdeen Proving Ground, ANL/ESD/TM-47, Argonne National Laboratory, Argonne, Ill.

Miller, S.F., et al., 1992a, Interim Progress Report - Geophysics: Building E5190 Decommissioning, Aberdeen Proving Ground, ANL/ESD/TM-33, Argonne National Laboratory, Argonne, Ill.

Miller, S.F., et al., 1992b, Interim Progress Report - Geophysics: Building E5476 Decommissioning, Aberdeen Proving Ground, ANL/ESD/TM-43, Argonne National Laboratory, Argonne, Ill.

Munsell Soil Color Charts, 1975, Macbeth, a division of Kollmorgen Corp., Baltimore, Md.

Oliveros, J.P., and P. Gernhardt, 1989, Hydrogeologic Data for the Canal Creek Area, Aberdeen Proving Ground, Maryland, April 1986-March 1988, U.S. Geological Survey Open-File Report 89-387.

Thompson, M.D., 1994, COLMX software, unpublished.

Thompson, M.D., et al., 1992a, Interim Progress Report - Geophysics: Building E5282 Decommissioning, Aberdeen Proving Ground, ANL/ESD/TM-36, Argonne National Laboratory, Argonne, Ill.

Thompson, M.D., et al., 1992b, Interim Progress Report - Geophysics: Building E5481 Decommissioning, Aberdeen Proving Ground, ANL/ESD/TM-44, Argonne National Laboratory, Argonne, Ill.

Thompson, M.D., et al., 1994, Interim Progress Report Addendum - Environmental Geophysics: Building E5032 Decommissioning, Aberdeen Proving Ground, January 1994 Resurvey, ANL/ESD/TM-85, Argonne National Laboratory, Argonne, Ill. 
Attachment:

Coordinates of Ground-Penetrating-Radar

Profiles at Building E3180 
Attachment:

Coordinates of Ground-Penetrating-Radar Profiles at Building E3180

\begin{tabular}{|c|c|c|c|c|c|c|c|c|c|}
\hline \multirow[b]{3}{*}{ Line No. } & \multicolumn{4}{|c|}{ Coordinates (ft) } & \multirow[b]{3}{*}{ Line No. } & \multicolumn{4}{|c|}{ Coordinates (ft) } \\
\hline & \multicolumn{2}{|c|}{ Start } & \multicolumn{2}{|c|}{ End } & & \multicolumn{2}{|c|}{ Start } & \multicolumn{2}{|c|}{ End } \\
\hline & $x$ & $Y$ & $\mathrm{X}$ & $Y$ & & $x$ & Y & $x$ & $Y$ \\
\hline 1 & \multicolumn{4}{|c|}{ Calibration line (begin $W \rightarrow E$ Lines) } & 31 & 165 & 190 & 165 & 150 \\
\hline 2 & 100 & 125 & 100 & 100 & 32 & 170 & 190 & 170 & 160 \\
\hline 3 & 105 & 130 & 105 & 100 & 33 & 175 & 190 & 175 & 160 \\
\hline 4 & 110 & 135 & 110 & 100 & 34 & 180 & 185 & 180 & 155 \\
\hline 5 & 115 & 140 & 115 & 100 & 35 & \multicolumn{4}{|c|}{ Calibration Line (Begin $W \rightarrow E$ Lines) } \\
\hline 6 & 120 & 145 & 120 & 100 & 36 & 100 & 100 & 235 & 100 \\
\hline 7 & 125 & 150 & 125 & 100 & 37 & 100 & 105 & 240 & 105 \\
\hline 8 & 130 & 155 & 130 & 100 & 38 & 100 & 110 & 240 & 110 \\
\hline 9 & 135 & 160 & 135 & 100 & 39 & 100 & 115 & 240 & 115 \\
\hline 10 & 140 & 165 & 140 & 100 & 40 & 100 & 120 & 240 & 120 \\
\hline 11 & 145 & 170 & 145 & 100 & 41 & 180 & 125 & 240 & 125 \\
\hline 12 & 150 & 175 & 150 & 100 & 42 & 180 & 130 & 240 & 130 \\
\hline 13 & 155 & 180 & 155 & 100 & 43 & 180 & 135 & 240 & 135 \\
\hline 14 & 160 & 185 & 160 & 100 & 44 & 180 & 140 & 240 & 140 \\
\hline 15 & 165 & 120 & 165 & 100 & 45 & 185 & 145 & 240 & 145 \\
\hline 16 & 170 & 120 & 170 & 100 & 46 & 185 & 150 & 240 & 150 \\
\hline 17 & 175 & 120 & 175 & 100 & 47 & 175 & 155 & 240 & 155 \\
\hline $1 \dot{8}$ & 180 & 120 & 180 & 100 & 48 & 135 & 160 & 240 & 160 \\
\hline 19 & 185 & 185 & 185 & 100 & 49 & 140 & 165 & 240 & 165 \\
\hline 20 & 190 & 185 & 190 & 100 & 50 & 145 & 170 & 225 & 170 \\
\hline 21 & 195 & 180 & 195 & 100 & 51 & 150 & 175 & 210 & 175 \\
\hline 22 & 200 & 180 & 200 & 100 & 52 & 160 & 180 & 200 & 180 \\
\hline 23 & 205 & 175 & 205 & 100 & 53 & 160 & 185 & 190 & 185 \\
\hline 24 & 210 & 175 & 210 & 100 & 54 & 100 & 125 & 160 & 125 \\
\hline 25 & 215 & 170 & 215 & 100 & 55 & 100 & 130 & 157 & 130 \\
\hline 26 & 220 & 170 & 220 & 100 & 56 & 105 & 135 & 155 & 135 \\
\hline 27 & 225 & 170 & 225 & 100 & 57 & 115 & 140 & 155 & 140 \\
\hline 28 & 230 & 165 & 230 & 100 & 58 & 120 & 145 & 160 & 145 \\
\hline 29 & 235 & 165 & 235 & 100 & 59 & 125 & 150 & 160 & 150 \\
\hline 30 & 240 & 160 & 240 & 100 & 60 & 130 & 155 & 160 & 155 \\
\hline
\end{tabular}


Appendix B:

Air Quality Monitoring Report 
April 6, 1995

TO: $\quad$ Eric Zimmerman

FROM: $\quad$ John Schneider $\ddot{\alpha} F$

SUBJECT : Building E3180 Air Monitoring for Volatile Organic Compounds

Building E3180 was built in 1944 and was a facsimile of a Japanese pillbox used by the research and development community in the development of flame weapon systems. The building was not used from 1957 to 1965 . From 1965 to the early 1970s, the building was used as a flame incendiary laboratory. From the early 1970 s until 1988 , the building was used as a metal working shop.

Air samples were collected and analyzed on-site at APG by ANL during the week of November 14, 1994. Samples were collected by drawing ambient air through a Tenax TA sorbent polymer sampling cartridge $(4 \mathrm{~mm} \mathrm{I.D.} \times 11.5 \mathrm{~cm}$ ) traps. at the rate of $200 \mathrm{~mL}$ for 120 minutes, yielding a $24 \mathrm{~L}$ sample volume. The cartridges were analyzed by thermally desorbing the trapped organic compounds with a Dynatherm model 900 ACEM thermal desorption unit on to a Hewlett-Packard 5890 series II gas chromatograph (GC) equipped with a Hewlett-Packard 5972 mass spectrometer (MS).

The MS was used for detecting and identifying organic compounds desorbed from the Tenax traps. Spectra were obtained by scanning from 45 to 400 atomic mass units at a rate of two scans every second. Identifications were based on mass spectral interpretation and computer searching of the 140,000 compound Wiley spectral library. A standard mixture of volatile organics containing toluene at $200 \mathrm{ng} / \mathrm{uL}$ and other aromatic hydrocarbons, was run daily to assure that the instrument was operating properly. All quantitations are estimates, using the assumption that analyte response factors should be similar to toluene in the standard mixture of volatile organics.

The majority of the volatile organic compounds found during the ANL air monitoring of Building 3180 are commonly found in any building (hydrocarbons and chlorinated solvents). The following compounds were the major components found in the air samples: 


$\begin{array}{lll}\text { Compound } & E 3180 & \text { Outside SW } \\ \text { Benzene } & 0.15 \mathrm{ng} / L & 0.05 \mathrm{ng} / L \\ \text { Toluene } & 0.32 \mathrm{ng} / L & 0.08 \mathrm{ng} / L \\ \text { Hexanal } & 0.02 \mathrm{ng} / L & 0.04 \mathrm{ng} / L \\ \text { Tetrachloroethene } & 0.09 \mathrm{ng} / L & 0.02 \mathrm{ng} / L \\ \text { Ethyl Benzene } & 0.07 \mathrm{ng} / L & 0.02 \mathrm{ng} / L \\ \text { Xylenes } & 0.24 \mathrm{ng} / L & 0.06 \mathrm{ng} / L \\ \text { Alpha Pinene } & 0.08 \mathrm{ng} / L & 0.02 \mathrm{ng} / L \\ \text { Benzaldehyde } & 0.16 \mathrm{ng} / L & 0.14 \mathrm{ng} / L \\ \text { Phenol } & 0.02 \mathrm{ng} / L & 0.02 \mathrm{ng} / L \\ \text { Beta Pinene } & 0.05 \mathrm{ng} / L & 0.01 \mathrm{ng} / L \\ \text { Methyl Phenyl Ketone } & 0.09 \mathrm{ng} / L & 0.14 \mathrm{ng} / L \\ \text { Naphthalene } & 0.03 \mathrm{ng} / L & 0.02 \mathrm{ng} / L\end{array}$

Figure 1 is a total ion chromatogram (TIC) of the air sample taken in E3180. Figure 2 is TIC of the outside air sample. Table 1 is the air sampling data sheet.

The analysis indicates that Building E3180 is not a source of volatile organic compound contamination. 

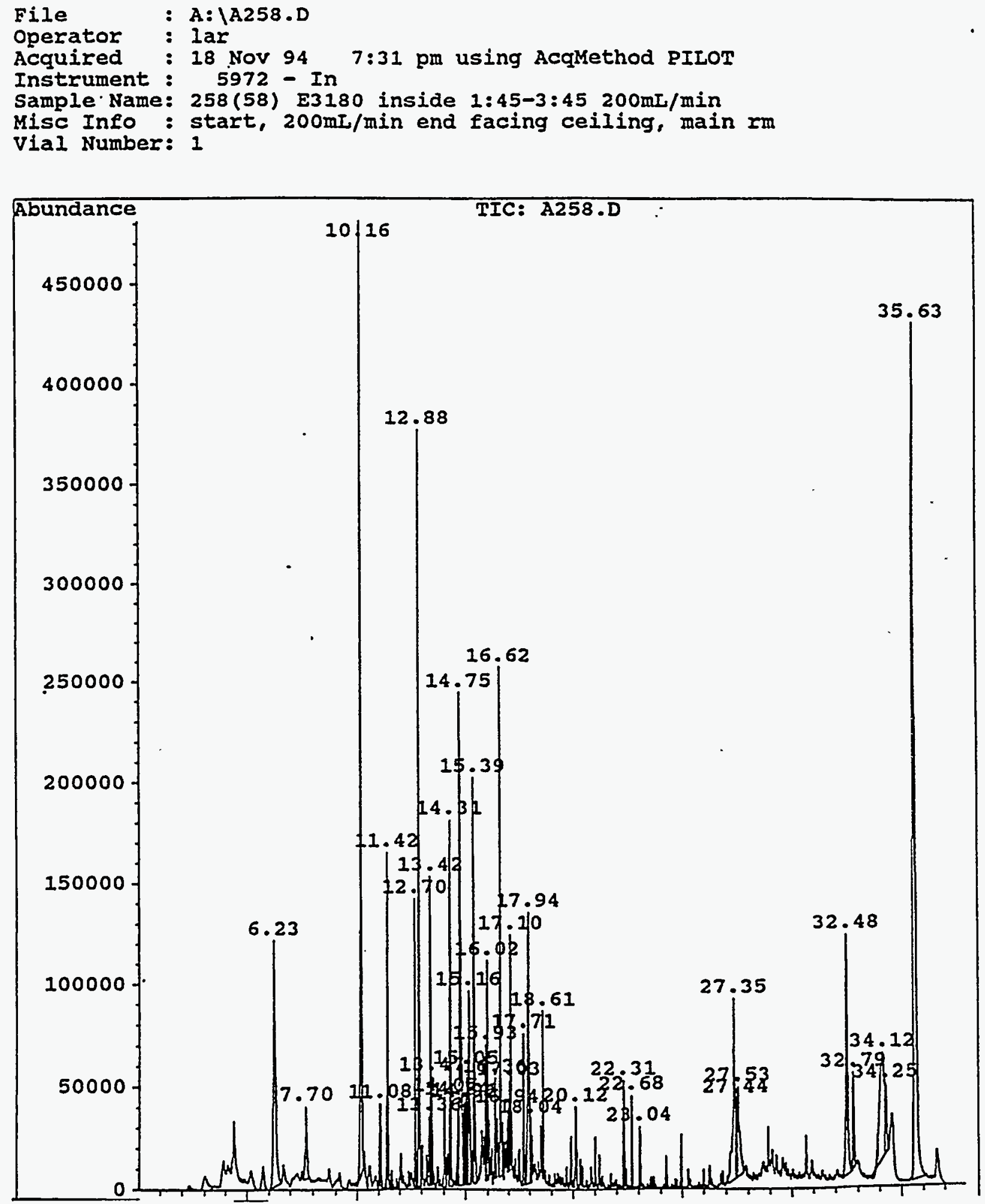
File : A: \A257.D

operator : lar

Acquired : 18 Nov $946: 42 \mathrm{pm}$ using AcqMethod PILOT

Instrument : 5972 - In

Sample Name: 257(45) E3180 outside $1: 40-3: 40$ 200m $/ \mathrm{min}$

Misc Info: start, $200 \mathrm{~mL} / \mathrm{min}$ end sw corner facing ceilin

Vial Number: 1

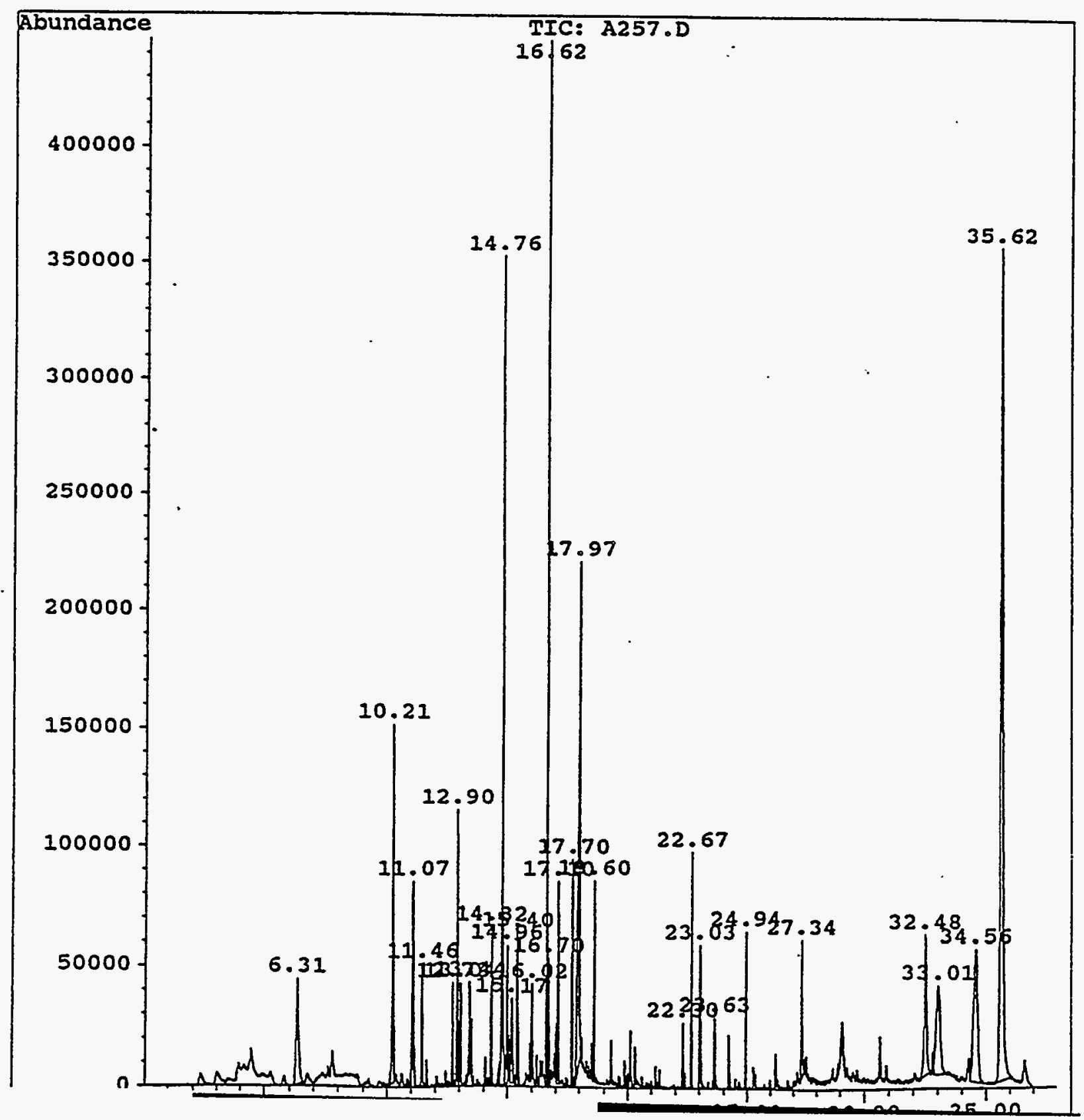




\begin{tabular}{|c|c|c|c|c|c|c|c|c|c|c|c|c|c|c|c|c|}
\hline \multicolumn{17}{|c|}{ Air Sampling Data Shoet } \\
\hline \multirow{2}{*}{\multicolumn{3}{|c|}{$111001+001$}} & \multirow{2}{*}{\multicolumn{7}{|c|}{ Sita: Rle:s-d...mn }} & \multirow{2}{*}{\multicolumn{7}{|c|}{ 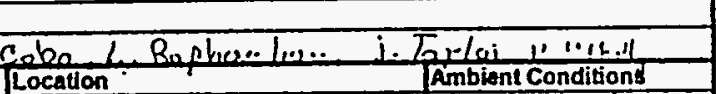 }} \\
\hline & & & & & & & & & & & & & & Ambien & IConditio & \\
\hline eer & Building & Room & $\begin{array}{l}\text { Sampl } \\
\text { Start }\end{array}$ & $\begin{array}{l}\text { Ung Time } \\
\text { End }\end{array}$ & $\begin{array}{c}\text { Flow } 1 \\
\text { Inittal }\end{array}$ & $\begin{array}{l}\text { Ralo } \\
\text { Final }\end{array}$ & $\begin{array}{l}\text { Pump } \\
\text { Sottling }\end{array}$ & Pump ID * & Manilotd & Helght & Distance :10 & Distance 2 & Facing & \begin{tabular}{|c|} 
Temp- \\
alure
\end{tabular} & Pressure & Humidtly \\
\hline का & $E 3161$ & $\cdots \cdots, 1-$ & & $12: 02$ & Pnom & $300 \frac{1}{\min }$ & $p$-ron & 4 & $I B$ & $1: \because$ & 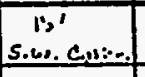 & & s.w. & 64 & - & 94 \\
\hline 77 & 63162 & 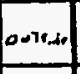 & $\therefore$ & 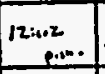 & $\therefore \cdots$ & 3 & Paso & 1 & $5 B$ & $11: " 1$ & (13.5. ‥pto e & & N.E. & 64 & - & $90 \%$ \\
\hline s? & $\cdot$ & $1 \ldots$ & $\therefore$ & 12:15 & . & Reo $\frac{n^{2}}{-i n}$ & 1. & .. & $\cdot \quad:$ & & $M \cdot E \cdot$ turat & & N.E. & 64 & - & $90 \%$ \\
\hline 5 & . : : & - ...: & $\therefore$ & $12 \cdot 15 \mathrm{en}$ & $\therefore$. & $200 \frac{26}{2}$ & $\cdot$ & & . & & N.E. Wall & & N.E. & 64 & - & $90 \%$ \\
\hline $\begin{array}{l}.6 \\
43 \\
\end{array}$ & $E 5625$ & ourde & $\begin{array}{l}8: 30 \\
A N\end{array}$ & $12 \div 30$ & $200 \mathrm{ml}$ & 300 & P.A.00 & 5 & $2 \pi$ & $16^{11}$ & NE of & & & $60 \%$ & & $54 \%$ \\
\hline \begin{tabular}{ll}
$-\pi$ \\
\hdashline \\
\end{tabular} & $\varepsilon 31 E 0$ & P.ind & $1: 40$ & $3: 40$ & $200 \mathrm{~mL}$ & $200 \frac{m}{m}$ & P.w & 13 & $2 B$ & $16^{\prime \prime}$ & 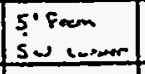 & 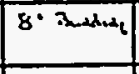 & Ceaning & $\eta_{1}=-$ & & $73 \%$ \\
\hline 258) & $2 \geq 100$ & 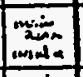 & 1.45 & $3 \cdot+j_{2}$ & $2 \omega \div$ & $200 \div$ & $p \cdot a$ & a. & $4 A$ & 16 & 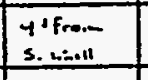 & $\begin{array}{l}\text { D. Fram } \\
\text { ine ...nor.r }\end{array}$ & Co.h. & $x^{\circ} \mathrm{k}$ & & $13 \%$ \\
\hline $\begin{array}{ll}531 \\
255 \\
\end{array}$ & $\varepsilon 3100$ & 位 & $t: v s_{2, \ldots}$ & $3.4 i_{1}, \ldots$ & 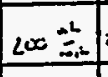 & $200 \frac{-1-4}{5}$ & ? & 2 & 43 & $16^{-}$ & $\begin{array}{l}4 \cdot \text { from } \\
\text { S. }-2,11\end{array}$ & $\begin{array}{l}2 \cdot \sin 1 \\
\text { w. . n }\end{array}$ & Cools & $21, \div$ & & $13 \%$ \\
\hline & & & & & & & & & & & & $\cdot$ & & & & \\
\hline & & & & & & & & & & & & & & & & \\
\hline & & & & & & & & & & & & & & & & \\
\hline & & & & & & & & & & & & & & & & \\
\hline & & & & & & & & & & & & & & & & \\
\hline & & & & & & & & & & & & & & & & \\
\hline & & & & & & & & & & & & & & & & \\
\hline
\end{tabular}


